\title{
Diaceratherium lemanense (Rhinocerotidae) from Eschenbach (eastern Switzerland): systematics, palaeoecology, palaeobiogeography
}

\author{
Damien Becker, Porrentruy, Toni Bürgin, St. Gallen, Urs Oberli, St. Gallen and \\ Laureline Scherler, Fribourg
}

With 9 figures and 10 tables

Becker, D., Bürgin, T., Oberli, U. \& Scherler, L. (2009): Diaceratherium lemanense (Rhinocerotidae) from Eschenbach (eastern Switzerland): systematics, palaeoecology, palaeobiogeography. - N. Jb. Geol. Paläont. Abh., 254: 5-39; Stuttgart.

\begin{abstract}
This paper describes a juvenile rhinocerotid skull from Eschenbach (eastern Switzerland). Computed tomography revealed the presence of the unerupted adult teeth P4 and M3 and enabled their three dimensional virtual reconstruction. The morphological features of this skull (postglenoid and posttympanic apophyses in contact, deep nasal notch, very slight occipital elevation, molar lingual cingulum absent, strong molar crochet) ascribe it to an evolved form of Diaceratherium lemanense (POMEL 1853) when compared with other European specimens. The diacerathere lineage is restricted to the Western European basins, except for the occurrences of the primitive $D$. cf. lamilloquense in the late Oligocene deposits of Nong Ya Plong (Thailand, Asia) and Diaceratherium askazansorense in the early Miocene of the Askazansor Formation (south-western Betpakdala, southern Kazakhstan, Asia). The Eschenbach locality represents a new biostratigraphical pinpoint at the Aquitanian (early Miocene), probably at the base of the MN2a Mammal Zone (Granitischer Sandstein Formation, upper part of the Lower Freshwater Molasse, USM, eastern Swiss Molasse Basin). A review of the European diacerathere record is proposed from the First Appearance Data of D. lamilloquense (MP29, La Milloque) to the Last Appearance Data of D. cf. aurelianense (MN4b, Eggingen-Mittelhart). During this time interval, the diacerathere lineage points to climatic stress and environmental changes. An ecological and spatio-temporal evolution in three phases between the "Terminal Oligocene Crisis" (disappearance of the ronzothere lineage) and the "Proboscidean Datum Event" at the late early Miocene (first European occurrence of the overtaking Brachypotherium) is suggested: 1) the Diaceratherium genus arrive in Europe during the latest Oligocene (the faunal renewal phase); 2) high diversity of the diacerathere group during the Aquitanian (the diversification phase); 3) wide geographical expansion of the last representatives (D. aurelianense) of the lineage during the Burdigalian (the stabilisation \& geographical expansion phase).
\end{abstract}

Key words: Rhinocerotidae, Diaceratherium, Oligo-Miocene transition, biostratigraphy, palaeobiogeography, tomography.

\section{Introduction}

The European diacerathere group was widely spread through the Oligo-Miocene transition. Its systematics is relatively well-known from DePÉRET \& DOUXAMI
(1902), RÉPELIN (1917), Dietrich (1931), DE Bonis (1973), Michel (1983), Brunet et al. (1987), GinsBURG et al. (1991, 2000) and CERDEÑo (1993), but palaeoecological and palaeobiogeographical approaches are limited. The diaceratheres represent the 
most common group among the large European rhinocerotids during the end of the Oligocene and the beginning of the Miocene (BRUNET et al. 1987, Prothero \& Schoch 1989, Prothero et al. 1989, Cerdeño 1998, Heissig 1999, Antoine 2002, BECKER 2003). This lineage occurs in Europe after the disappearance of Ronzotherium romani from Rickenbach (Switzerland) in MP29, which is the last representative of the ronzothere group (LAD = Last Appearance Data; BRUNET et al. 1987, ENGESSER \& MöDden 1997, EMery 2004, Emery et al. 2007). The diaceratheres belong to a more advanced group of the Rhinocerotini (ANTOINE 2002), characterised by mediportal and graviportal anatomical types. They seem to be restricted to the Western European basins, except for the occurrence of a Diaceratherium cf. lamilloquense in the late Oligocene lignite deposits of the Nong Ya Plong Tertiary Basin in Central Thailand (MARIVAuX et al. 2004), which could be the first representative of the group $(\mathrm{FAD}=$ First Appearance Data). Furthermore, KoRDIKOvA (2001) describes some bone and tooth remains of a new species of diacerathere, Diaceratherium askazansorense, in the early Miocene of the Askazansor Formation (southwestern Betpakdala, southern Kazakhstan, Asia), which currently is the only Miocene representative of the group outside Europe.

Although Prothero (1999) suggests that the mammalian fauna shows few short-term responses to climatic events during the Cenozoic, it is nevertheless clear that land plants and other elements of the terrestrial biota are responding. Cause-and-effect relationships between short-term climatic and mammalian faunal changes may exist, but a very high resolved chrono- and biostratigraphy have to be established before these hypotheses can be evaluated. On the other hand, numerous changes in the mammal communities are assumed to be due to sea-level changes, plate tectonics and climatic fluctuations (HoOKer 2000, Whybrow \& ANDrews 2000). Moreover, some proxies such as body mass, body size, diet, hypsodonty (crown height), locomotion, taxonomical changes, species richness, abundance and commonness to assess the evolutionary responses of mammals to climatic and environmental changes are used by numerous palaeoecological studies (JANIS 1986, Legendre 1989, Cerdeño \& Nieto 1995, JERNVALL \& FORTELIUS 2002, JANIS et al. 2004, Costeur 2005, Fortelius et al. 2006). According to Cerdeño \& Nieto (1995), Cerdeño (1998) and BECKER (2003) the changes in the composition of rhinocerotid populations result mainly from climatic and environmental variations, and from competition due to migration.

During the Oligocene, the climate is marked by a slightly progressive degradation, but seems stable with dominating temperate conditions reflected by a relative faunal stability and woodland environments in the northern hemisphere (JANIS 1993). However, some authors (e.g. HAQ et al. 1987, SCHUlER 1990, Prothero 1994) point out a cooling event in the mid-Oligocene associated with a major sea level regression, but this event was not associated by very significant extinctions. Nonetheless, disappearances (e.g. Epiaceratherium, Gelocus), regional speciations (e.g., Eggysodon gaudryi, Lophiomeryx chalaniati, Ronzotherium romani), and immigrations (e.g. Bachitherium, Protaceratherium albigense) can be recognized during the interval MP 23-25 in Europe. In addition, the last occurrence of three ruminant families (Bachiteriidae, Gelocidae, Lophiomericidae), the diversification of some rodent groups (e.g. Eomyidae), and the first occurrences of typical late Oligocene mammals as Microbunodon or Moschidae (see Brunet 1979, Blondel 1997, Uhlig 1999, Engesser \& Mödden 1997, Vianey-Liaud 2003 and LIHOREAU \& DUCROCQ 2007) are observed in MP 28. These faunal changes seem to be related to the "Late Oligocene Warming" known from the isotope record (ZACHOs et al. 2001) and the regional temperature peak recorded from palaeofloral data of Central Europe (MosBrugGer et al. 2005). After this warming event, numerous authors emphasize a drastic climatic change in Western Europe, starting in the latest Oligocene and marked by a general aridification and cooling (BERGER 1989, 1990a, 1990b, SCHLunEGGer et al. 2001, Becker 2003, Costeur 2005). This climatic event ("Late Chattian Climatic Crisis" of BECKER 2003, 2004) is herein named the "Terminal Oligocene Crisis" (at ca. $24 \mathrm{Ma}$ ) and is essentially linked to disappearances and migrations of large mammals, particularly within the rhinocerotid (disappearance of Ronzotherium and arrival of Diaceratherium) and anthracotherid lineages (disappearance of Anthracotherium and Microbunodon). At the global scale a major glaciation at the Oligo/Miocene boundary - which corresponds to a rare orbital congruence involving obliquity and eccentricity supports the expansion of ice-sheet on Antarctic. This event, called "Mi-1", marks a fundamental shift in the climate, which accelerates the rates of turnover and speciation in certain groups of biota (ZACHOs et al. 
Fig. 1. Geographical and geological setting of the sandstone quarry of Eschenbach (Aquitanian, eastern Switzerland).

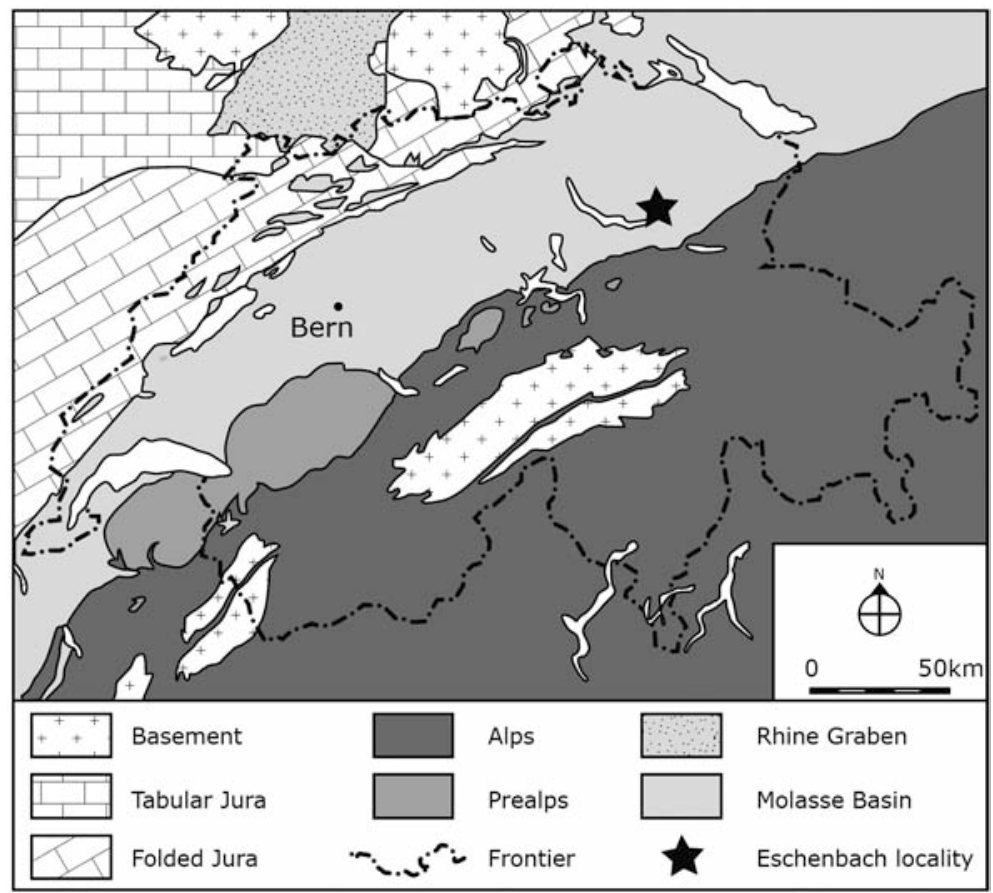

2001). During the earliest Miocene the general conditions remain dry but the environments become scattered in mosaic subenvironments (COSTEUR 2005). The environment of Saulcet (MN1, France) is arid and rather closed, whereas the environment of Wischberg (MN1, Switzerland) is clearly open and dry. During the MN2 biozone, the Aquitanian Basin is subdesertic with a vegetation of bushland type, the Massif Central open and humid with a probable vegetation of edaphic grassland type, Switzerland and Germany are covered by more or less arid and closed woodlands, and the Iberian Peninsula landscapes are mostly open and dry. At the late early Miocene, the environments are closed again and associated with a rather wet climate (COSTEUR 2005). However, BöHME (2003) links the beginning of the "Miocene Climatic Optimum" in Central Europe with two successive migrations (20 Ma and $18 \mathrm{Ma}$ ) of ectothermical and thermophile vertebrates adapted to dry conditions. According to TASSY (1989), GöHLICH (1999) and RöGL (1999), the initiation of this climatic event occurs just before the palaeobiogeographic "Proboscidean Datum Event" (at ca. 17.5 Ma).

The focus of this study is the description of a new skull of a juvenile Diaceratherium lemanense (POMEL 1853) recently discovered in Eschenbach (Canton St. Gallen, Switzerland). By using a computed tomography of unerupted adult teeth, the ontogeny of this specimen is discussed. The morphometrical and biometrical features of this skull are described as well as its evolutionary state, allowing its identification to an evolved form of $D$. lemanense. Finally the palaeobiogeographical and the palaeoeological evolution of the diaceratheres is clarified (based upon an abundant European fossil record), in order to shed some light on the environmental evolution of the Western European basins during the Oligo-Miocene transition (from the "Terminal Oligocene Crisis" to the "Proboscidean Datum Event").

\section{Geological setting}

The Eschenbach locality is a sandstone quarry, near the north-eastern end of the Lake Zürich (eastern Switzerland; Swiss federal coordinates 712.700/ 232.220), at the southern border of the folded Plateau Molasse, just north of the Subalpine Molasse boundary (Fig. 1). The sandstones are exploited for construction and renovation of buildings by the Müller AG Company (Neuhaus, Canton St. Gallen, Switzerland). Actually, the excavation presents a roughly $60 \mathrm{~m}$ deep extraction, exposing subvertical layers of Granitischer Sandstein (KaUfMANN 1860). According to HaBICHT (1987), the Granitischer Sandstein Formation is commonly used for the geological mapping, whereas the Granitische Molasse of STUDER (1853) 


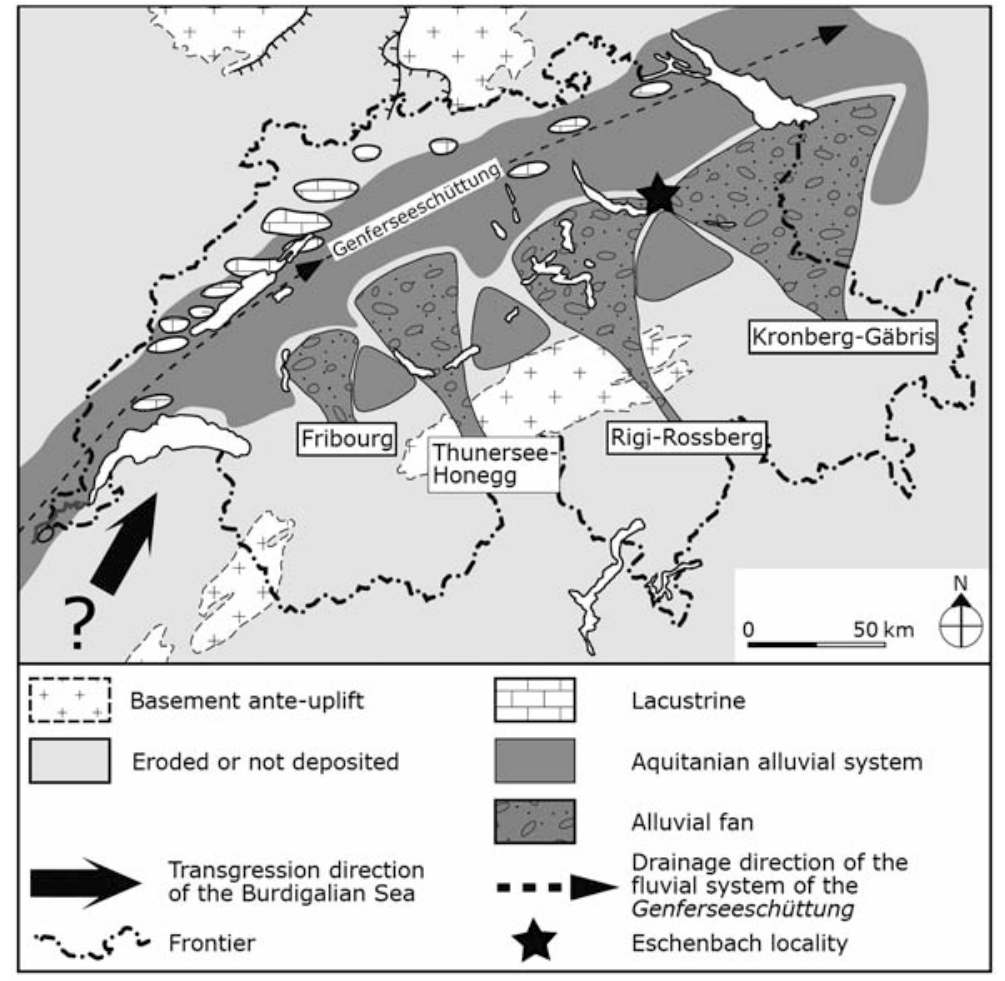

Fig. 2. Palaeogeographical situation of the Swiss Molasse Basin during the Aquitanian (modified after BERGER et al. 2005). and the Bollinger Sandstein of KAUFMANN (1860) are just synonyms. The sandstone deposits of Eschenbach quarry are all dated to the Aquitanian and they belong to the upper part of the USM (Untere Süsswasser Molasse = Lower Freshwater Molasse, ChattianAquitanian). Palaeogeographically, the Eschenbach locality is located at a triple point, north of the alluvial fans Rigi-Rossberg Schüttung and Kronberg-Gäbris Schüttung, and south of the vast Aquitanian fluvial system of the Genferseeschüttung drained eastwards (Fig. 2).

Chattian-Aquitanian mammal localities with precise biostratigraphical data are rare in eastern Switzerland. Engesser \& MöDden (1997) report EbnatKappel (MP28; Frei 1979, ENGESSER 1990, MöDdEN 1994) from the Ebnater Sandstein Formation (HEIM 1902), while Wintersberg/Trempel (MP30; FREI 1979) and Sparenweid (= Greit, Höhronen; MN1; SCHLANKE 1974) are both from the WintersbergSchichten Formation (HABICHT 1945). BECKER (2003) illustrates dental remains of a Ronzotherium romani in Rüf bei Schänis (MP29; FrEI 1979) also originating from the Wintersberg-Schichten Formation. Moreover, an unpublished mandible of a chalicothere discovered near Bollingen ( $3 \mathrm{~km}$ west of Eschenbach), from the same lithostratigraphical level than the reported skull, is stored in the collection of the Paläontologisches Institut und Museum of the University of Zürich (Heinz Furrer, pers. comm.). The Eschenbach locality is also of biostratigraphical interest for the Aquitanian of the eastern part of the Swiss Molasse Basin and has implications for diacerathere palaeobiogeography.

\section{Material and methods}

\subsection{Material}

The reported material is a complete juvenile skull of a Diaceratherium lemanense (NMSG-P2006/1), stored in the collection of the Naturmuseum of St. Gallen (Switzerland). It was discovered by Reto Zwicky (Uznach, St. Gallen, Switzerland), who did a first preparation of the material using relatively coarse tools, as the specimen was initially trapped in a very hard sandstone block. The final preparation was accomplished by one of us (U. O.), using appropriate instruments (e.g. air tool).

\subsection{Systematics}

The identification is based on anatomical feature descriptions, compared anatomy and biometrical measurements, following the method of GUÉRIN 
Table 1. Specimens used for anatomical comparisons.

\begin{tabular}{|c|c|c|c|c|c|c|}
\hline $\begin{array}{l}\text { Diacerathe- } \\
\text { rium species }\end{array}$ & Locality & $\begin{array}{l}\text { Ana- } \\
\text { tomy }\end{array}$ & $\begin{array}{l}\text { Inventory } \\
\text { number }\end{array}$ & Reference & $\begin{array}{l}\text { Direct } \\
\text { observa- } \\
\text { tion }\end{array}$ & Housing institution \\
\hline $\begin{array}{l}D . \\
\text { lamilloquense }\end{array}$ & La Milloque (France) & $\begin{array}{l}\text { isolated } \\
\text { upper } \\
\text { teeth }\end{array}$ & - & $\begin{array}{l}\text { DE BONIS 1973, MICHEL } \\
1983\end{array}$ & no & $\begin{array}{l}\text { Muséum d'histoire naturelle de } \\
\text { Marseille, France (UPM) }\end{array}$ \\
\hline $\begin{array}{l}\text { D. aff. } \\
\text { lemanense }\end{array}$ & Paulhiac (France) & $\begin{array}{l}\text { isolated } \\
\text { upper } \\
\text { teeth }\end{array}$ & - & $\begin{array}{l}\text { DE BONIS 1973, MICHEL } \\
1983\end{array}$ & no & $\begin{array}{l}\text { Muséum d'histoire naturelle de } \\
\text { Marseille, France (UPM) }\end{array}$ \\
\hline $\begin{array}{l}\text { D. } \mathrm{cf} . \\
\text { lemanense }\end{array}$ & Engehalde (Switzerland) & skull & $\begin{array}{l}\text { NMBE-D } \\
3193\end{array}$ & $\begin{array}{l}\text { OOSTER \& FISCHER- } \\
\text { OOSTER } 1871\end{array}$ & yes & $\begin{array}{l}\text { Naturhistorisches Museum of } \\
\text { Bern, Switzerland (NMBE) }\end{array}$ \\
\hline \multirow[t]{4}{*}{ D. lemanense } & Gannat (France) & skull & - & ROMAN 1911 & no & $\begin{array}{l}\text { Muséum national d'histoire } \\
\text { naturelle de Paris, France } \\
\text { (MNHN) }\end{array}$ \\
\hline & $\begin{array}{l}\text { Saint-Gérand-le-Puy } \\
\text { (France) }\end{array}$ & $\begin{array}{l}\text { isolated } \\
\text { upper } \\
\text { teeth }\end{array}$ & - & BRUNET et al. 1987 & no & unknown \\
\hline & Cindré (France) & $\begin{array}{l}\text { upper } \\
\text { jaw }\end{array}$ & - & ROMAN 1911 & no & $\begin{array}{l}\text { Baillaud collection in Perfitte- } \\
\text { sur-Loire (after ROMAN 1911) }\end{array}$ \\
\hline & $\begin{array}{l}\text { Eschenbach } \\
\text { (Switzerland) }\end{array}$ & skull & $\begin{array}{l}\text { NMSG-P } \\
2006 / 1\end{array}$ & This study & yes & $\begin{array}{l}\text { Naturmuseum of St. Gailen, } \\
\text { Switzerland (NMSG) }\end{array}$ \\
\hline \multirow[t]{3}{*}{ D. asphaltense } & $\begin{array}{l}\text { Pyrimont-Challonges } \\
\text { (France) }\end{array}$ & skull & $\begin{array}{l}\text { UCBL- } \\
212997\end{array}$ & $\begin{array}{l}\text { DEPÉRET \& DOUXAMI } \\
1902\end{array}$ & yes & $\begin{array}{l}\text { Université Claude-Bernard } \\
\text { Lyon-Villeurbanne, France } \\
\text { (UCBL) }\end{array}$ \\
\hline & Saulcet (France) & skull & $\begin{array}{l}\text { NMB-SAU } \\
1662\end{array}$ & This study & yes & $\begin{array}{l}\text { Naturhistorisches Museum of } \\
\text { Basle, Switzerland (NMB) }\end{array}$ \\
\hline & $\begin{array}{l}\text { Wischberg } \\
\text { (Switzerland) }\end{array}$ & skull & NMB-AS75 & $\begin{array}{l}\text { SCHAUB \& HÜRZERLER } \\
1948\end{array}$ & yes & $\begin{array}{l}\text { Naturhistorisches Museum of } \\
\text { Basle, Switzerland (NMB) }\end{array}$ \\
\hline $\begin{array}{l}D . \\
\text { tomerdingense }\end{array}$ & $\begin{array}{l}\text { Tomerdingen } \\
\text { (Germany) }\end{array}$ & $\begin{array}{l}\text { isolated } \\
\text { upper } \\
\text { teeth }\end{array}$ & - & DIETRICH 1931 & no & $\begin{array}{l}\text { Staatliches Museum für } \\
\text { Naturkunde Stuttgart, Germany } \\
\text { (SMNS) }\end{array}$ \\
\hline \multirow[t]{2}{*}{ D. aginense } & Laugnac (France) & skull & - & $\begin{array}{l}\text { RÉPELIN 1917, DE BONIS } \\
\text { 1973, MICHEL } 1983\end{array}$ & no & $\begin{array}{l}\text { Muséum d'histoire naturelle de } \\
\text { Marseille, France (UPM) }\end{array}$ \\
\hline & Béthusy (Switzerland) & $\begin{array}{l}\text { upper } \\
\text { jaw }\end{array}$ & MGL-3356 & ENGESSER et al.1993 & yes & $\begin{array}{l}\text { Musée cantonal de géologie of } \\
\text { Lausanne, Switzerland (MGL) }\end{array}$ \\
\hline D. aurelianense & $\begin{array}{l}\text { Neuville-aux-Bois } \\
\text { (France) }\end{array}$ & skull & - & $\begin{array}{l}\text { NOUEL 1866, CERDEÑO } \\
1993\end{array}$ & no & $\begin{array}{l}\text { Muséum national d'histoire } \\
\text { naturelle de Paris, France } \\
\text { (MNHN) }\end{array}$ \\
\hline
\end{tabular}

(1980) and the cladistic characters of CERDEÑO (1995) and Antolne (2002). The specimens used for comparison and the abbreviations of the housing institutions are listed in Table 1. The other abbreviations are reported in Table 2. All measurements are given with a precision of $0.5 \mathrm{~mm}$.

\subsection{Tomography analyses, modelling and rapid prototyping}

The computed tomography (CT) was performed on the roughly prepared Eschenbach rhinocerotid skull by the Abteilung Elektronik, Messtechnik, Zuverlässigkeit of the EMPA in Dübendorf (Switzerland). 920 scans were made at $450 \mathrm{kV}$ and at an interval of $0.5 \mathrm{~mm}$. This allowed producing $3 \mathrm{D}$ reconstructions of the skull, which was trapped in a $20 \mathrm{~cm}$ wide sandstone block. The CT-scans have been processed by
Medical Software Mimics in the Institute for Rapid Product Development (RPD) of St. Gallen (Switzerland). Two types of rapid prototype modelling were performed: a Photopolymer model and a Polyamid-12 model. The details of these analytical methods, not relevant for the present paper, are explained in Schindel et al. (2008). In this study, we describe in the ontogenical analysis two casts of unerupted adult teeth ( $\mathrm{P} 4$ sin. and M3 sin.), which were made based on the $\mathrm{CT} 3 \mathrm{D}$ reconstructions.

\subsection{Locality distribution data}

The analysis of the palaeoecological and spatiotemporal evolution of the European diaceratheres is based on 57 Diaceratherium localities, recorded in the Iberian Peninsula (Spain and Portugal), France, Switzerland and Germany (Tab. 3). The biostrati- 
Table 2. Abbreviations used in this study.

\begin{tabular}{llll}
\hline Dentition & & \\
\hline $\mathrm{M}$ & upper molar & $\mathrm{i}$ & lower incisive \\
$\mathrm{m}$ & lower molar & $\mathrm{D}$ & upper milk tooth \\
$\mathrm{P}$ & upper premolar & $\mathrm{d}$ & lower milk tooth \\
$\mathrm{p}$ & lower premolar & TR & toothrow \\
$\mathrm{I}$ & upper incisive & &
\end{tabular}

\begin{tabular}{|c|c|c|c|}
\hline \multicolumn{4}{|c|}{ Postcranial skeleton } \\
\hline $\mathrm{Mc}$ & metacarpus & $\mathrm{Mt}$ & metatarsus \\
\hline \multicolumn{4}{|c|}{ Biometry } \\
\hline dext. & right & TD & transversal diameter \\
\hline $\sin$. & left & abs & absolute \\
\hline Dist. & distance & anat & anatomic \\
\hline $\mathrm{L}$ & length & TDT & transversal diameter of \\
\hline W & width & & the astragalus trochlea \\
\hline $\mathrm{H}$ & height & TD dia & $\begin{array}{l}\text { transversal diameter in } \\
\text { the middle of the } \\
\text { diaphysis }\end{array}$ \\
\hline
\end{tabular}

\begin{tabular}{llll}
\hline Index & & & \\
\hline $\mathrm{I}-\mathrm{Gr}$ & gracility index based & $\mathrm{I}-\mathrm{Hy}$ & hypsodonty index \\
(Mc) & $\begin{array}{l}\text { on Mt } \\
\text { I-Gr }\end{array}$ & & \\
gracility index based & & \\
& & & \\
\hline on Mc & & & \\
\hline $\mathrm{Br}-\mathrm{B}$ & browser brachyodont & $\mathrm{Br}-\mathrm{H}$ & browser hypsodont \\
$\mathrm{Br}-\mathrm{M}$ & browser mesodont & $\mathrm{Gr}-\mathrm{H}$ & grazer hypsodont \\
\hline
\end{tabular}

graphy of the localities is updated using recent works of Tobien (1980), Cerdeño (1993), Engesser et al. (1993), CERDEÑo \& Nieto (1995), Hugueney (1997), Heissig (1999), Antoine et al. (2000), Ginsburg et al. (2000), SACH \& HeIZMANN (2001), BecKer (2003), Costeur (2005) and Fortelius (2003). The sampling includes mainly the common Diaceratherium species (D. lemanense, D. asphaltense, D. aginense and D. aurelianense). Additionally, the unusual local species $D$. lamilloquense and $D$. tomerdingense are also considered in order to complete the data.

To estimate the sampling effects, the commonness (locality coverage) of the Diaceratherium locality record is related to that of 178 large mammal localities and is assessed per million years within the considered biozones. The small mammal localities (no more taxa than rodents, lagomorphs, insectivores and cainotheres) are excluded to even out the sampling bias. The considered stratigraphical interval corresponds to the Oligocene-Miocene transition, from MP29 to MN4. The chronostratigraphy of the MP and MN biozones is calibrated after ENGESSER \& MöDdEN (1997), KempF et al. (1997), Mein (1999), Schmidt-Kittler et al. (1997) and Steininger (1999). All data on localities (Tab. 4), species and chronostratigraphical correlations are obtained from the existing database "Neogene of the Old World" (cf. ForTelius 2003: NOW public release, July 2003), from the literature (see references in Tabs. 3-4) and also from several unpublished collections from NMB and NMBE (only for the Diaceratherium localities).

\subsection{Maps}

All recorded Diaceratherium localities have been plotted on modern maps of Western Europe to illustrate the biogeographical distribution (contractions, expansions, fragmentations). Modern geographical names (Iberian Peninsula, France, Switzerland and Germany) are also used as landmarks, but backgrounds of European Tertiary basins are added for each map to control the sampling effects. Because of the map scale, the localities with very close coordinates are plotted in the same point (see Fig. 6).

\subsection{Palaeoecology}

A part of the specimens used for the palaeoecological analyses has been directly studied in the related collections. The data of the other specimens are from the literature. The palaeoecological parameters of Diaceratherium species have been characterised in order to define the anatomical types and diets. Following Cerdeño \& Nieto (1995), the body size has been estimated from the transversal diameter of the astragalus trochlea (TDT), which indicates the relative size of the animal (shoulder height). Body mass has been estimated from the $\mathrm{m} 1$ area, following the formula of LEGENDRE (1989): $\ln X=\ln Y$ x 1.564 +3.267 , where $X=$ weight and $Y=m 1$ area. Slenderness has been measured mainly from the McIII and secondary from MtIII and McII following the method of the gracility index (GUÉRIN 1980): 100 x TDdia / L. The diets have been estimated thanks to the description of the patterns of the back tooth occlusal view and by calculating the upper back tooth hypsodonty index (sensu GUÉRIN 1980, on P3-M2 for more reliable results: $100 \times \mathrm{H} / \mathrm{L}$ ). According to FORTELIUS et al. (2006), brachyodont teeth have a ratio less than 80 , mesodont are in the range of 80-120 and hypsodont over 120. The head holding (feeding posture) is a function of the feeding behaviour, which can be characterised from skulls, by using the occipital side inclination and the angle of the occipital crest in lateral view (BALES 1996). The different categories of palaeoecological parameters are exposed in Table 5 . 
Table 3. Biostratigraphical distribution of the European Diaceratherium localities.

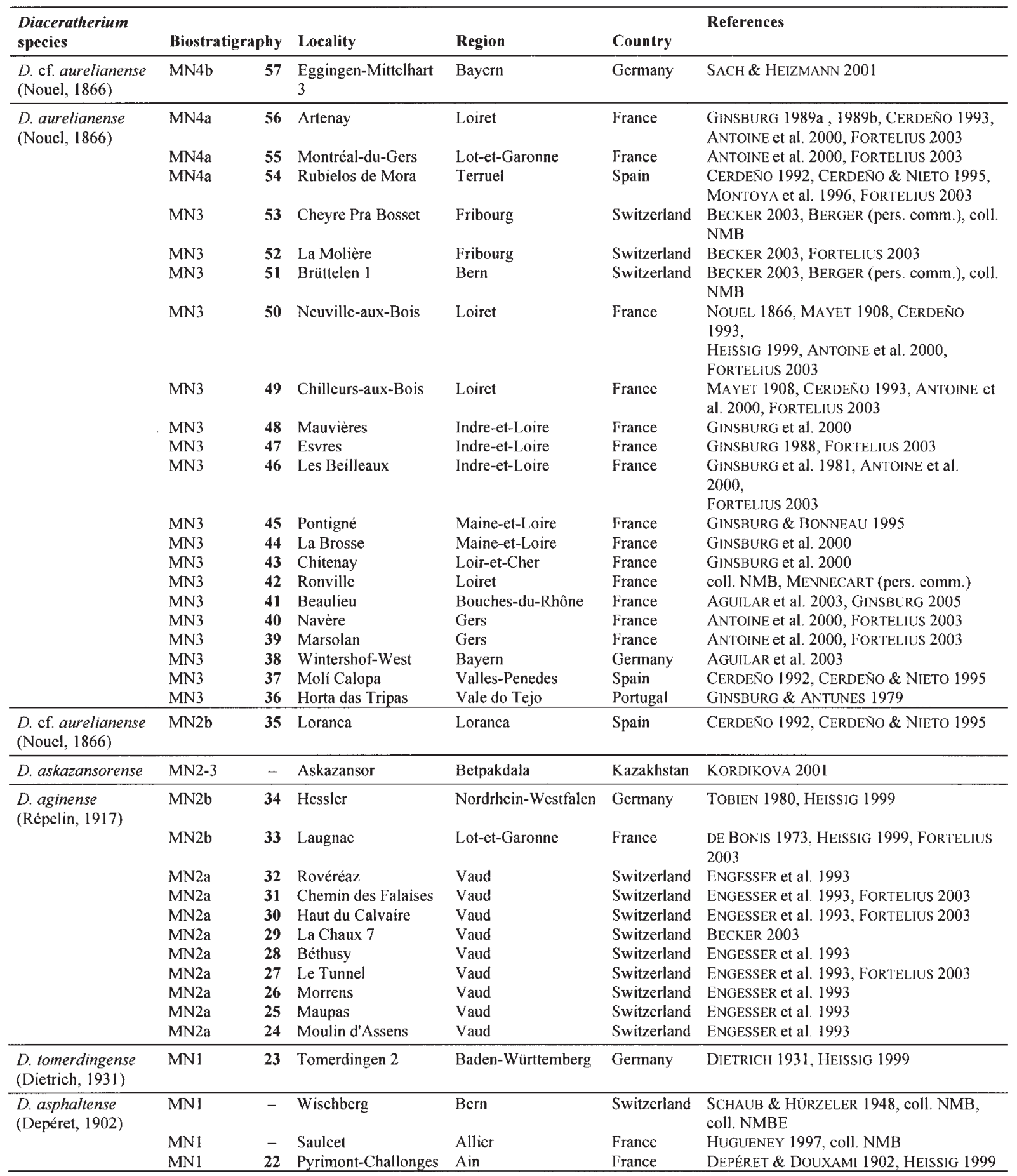

The dietary subdivisions used in this paper are mainly based on those of JANIS (1986). We consider grazing rhinocerotids (at least $90 \%$ of the year round diet in form of monocotyledonous grass materiel) and browser rhinocerotids (at least $90 \%$ of the year round diet in form of dicotyledonous herbage). The latter are tree and shrub foliage eaters and are divided into "high browsers feeding above ground level" and 
Table 3. (continued)

\begin{tabular}{|c|c|c|c|c|c|c|}
\hline \multirow{2}{*}{$\begin{array}{l}\text { D. lemanense } \\
\text { (Pomel, 1853) }\end{array}$} & $\mathrm{MN} 2 \mathrm{~b}$ & 21 & Budenheim & Mainz & Germany & ROMAN, 1924, TOBIEN 1980 \\
\hline & MN2b & 19 & Selles-sur-Cher & Loir-et-Cher & France & $\begin{array}{l}\text { ROMAN 1911, GINSBURG \& HUGUENEY } \\
1980\end{array}$ \\
\hline evolved form & $\mathrm{MN} 2 \mathrm{a}$ & 18 & Eschenbach & St. Gallen & Switzerland & this study \\
\hline evolved form & $\mathrm{MN} 2 \mathrm{a}$ & 17 & Montaigu-le-Blin & Allier & France & $\begin{array}{l}\text { Hugueney 1997, Fortelius 2003, coll. } \\
\text { NMB }\end{array}$ \\
\hline evolved form & MN2a & 16 & Saint-Gérand-le-Puy & Allier & France & BRUNET et al. 1987, HUGUENEY 1997 \\
\hline \multirow[t]{5}{*}{ primitive form } & MN1-2 & 14 & Cindré & Allier & France & ROMAN 1911, HUGUENEY 1997 \\
\hline & MN1 & 13 & Oppenheim & Mainz & Germany & TOBIEN 1980 \\
\hline & $\mathrm{MNl}$ & 12 & Weisenau & Mainz & Germany & TOBIEN 1980, FORTELIUS 2003 \\
\hline & $\mathrm{MN} \mathrm{l}$ & 11 & Finthen & Mainz & Germany & TOBIEN 1980 \\
\hline & MNI & 10 & Wischberg & Bern & Switzerland & $\begin{array}{l}\text { SCHAUB \& HÜZELLER 1948, coll. NMB, } \\
\text { coll. NMBE }\end{array}$ \\
\hline primitive form & MN1 & 6 & Métro de Toulouse & Haute-Garonne & France & ANTOINE ET AL 2006 \\
\hline $\begin{array}{l}\text { D. cf. lemanense } \\
\text { (Pomel, 1853) }\end{array}$ & MN1-2 & 5 & Engehalde & Bern & Switzerland & $\begin{array}{l}\text { OOSTER \& FISCHER-OOSTER 1871, } \\
\text { STEHLIN 1914, BECKER 2003, coll. NMBE }\end{array}$ \\
\hline $\begin{array}{l}\text { D. lemanense } \\
\text { (Pomel, 1853) }\end{array}$ & MP30 & 4 & Rott bei Bonn & Nordrhein-Westfalen & Germany & $\begin{array}{l}\text { VON KOENIGSWALD ET AL. 1992, MÖRS } \\
2002\end{array}$ \\
\hline \multirow[t]{2}{*}{$\begin{array}{l}\text { D. aff. lemanense } \\
\text { (Pomel, 1853) }\end{array}$} & MN1 & 3 & Paulhiac & Lot-et-Garonne & France & $\begin{array}{l}\text { DE BONIS } 1973 \text {, BRUNET et al. } 1987 \text {, } \\
\text { FORTELIUS } 2003\end{array}$ \\
\hline & MP30 & 2 & Thézels & Lot & France & MICHEL 1983, BRUNET et al. 1987 \\
\hline $\begin{array}{l}\text { D. lamilloquense } \\
\text { (Michel, 1983) }\end{array}$ & MP29 & 1 & La Milloque & Lot-et-Garonne & France & MICHEL 1983, BRUNET et al. 1987 \\
\hline
\end{tabular}

"regular browsers feeding both above the ground and at ground level". Finally the intermediate feeders are defined as "mixed feeders" living in open habitats (savanna or prairie) or in closed habitats (bushland, woodland or forest).

To test the above methods, they were also applied to the extant rhinoceroses ( 4 genera, 5 species) and compared with the literature data from NowAK (1999) and Christiansen (2002). Except for the method of LEGENDRE (1989) - in which the estimated weights are generally higher, in particular for the relatively slender and large Diceros bicornis -, all methods match well with the five extant species. Among the fossil rhinocerotids, the weight estimates are probably considerably too high for the Ronzotherium species (slender and cursorial anatomical types). The Legendre's method seems not to be adequate for the slender forms $\left(\mathrm{r}^{2}=0.521\right)$, but it provides useful data for the mediportal and graviportal anatomical types $\left(r^{2}=0.8473\right)$. The regression of body mass on skull length (occipital condyles-premaxilla) shows a better correlation $\left(\mathrm{r}^{2}=0.9242\right)$, but the material does not always allow this measurement, therefore it has only been considered for the extant D. bicornis and for the extinct Ronzotherium species. Finally, the different anatomical types and diets defined for each Diaceratherium species and extant rhinoceroses have been compared in order to highlight analogies of the ecological parameters.

\section{Results}

\subsection{Systematics}

The suprageneric arrangement follows that proposed by ANTOINe (2002).

Order Perissodactyla Owen 1848

Family Rhinocerotidae GRAY 1821

Subfamily Rhinocerotinae GRAY 1821

Tribe Rhinocerotini GRAY 1821

Subtribe Teleoceratina HAY 1902

Genus Diaceratherium DIETRICH 1931 
Table 4. Biostratigraphical distribution of the European large mammal localities.

\begin{tabular}{|c|c|c|c|c|c|}
\hline \multirow{16}{*}{$\begin{array}{l}\text { Iberian } \\
\text { Peninsula }\end{array}$} & MN4 & $\mathrm{nM}=\mathbf{3 2}$ & Acacias (CERDEÑo \& NIETO 1995) & $\begin{array}{l}\text { El Casots (GENTRY et al. } \\
\text { 1999) }\end{array}$ & $\begin{array}{l}\text { Munebrega I-3, AB (CERDEÑO \& } \\
\text { NIETO 1995) }\end{array}$ \\
\hline & & & Artesilla (CERDEÑo \& NIETO 1995) & Lisboa (CERDEÑo 1992) & PAR-Pennelas (FORTELIUS 2003) \\
\hline & & & Buñol (GÖHLICH 1999) & $\begin{array}{l}\text { Puente Toledo (CERDEÑo \& } \\
\text { NiETO 1995) }\end{array}$ & $\begin{array}{l}\text { Paseo de las Acacias (FORTELIUS } \\
\text { 2003) }\end{array}$ \\
\hline & & & Can Julia (CERDEÑo \& NIETO 1995) & $\begin{array}{l}\text { Quinta da Farinheira } \\
\text { (GOHLICH 1999) }\end{array}$ & $\begin{array}{l}\text { Rubielos de Mora (MONTOYA et al. } \\
\text { 1996) }\end{array}$ \\
\hline & & & Can Mas (CERDEÑO \& NIETO 1995) & Quinta da Noiva (VAN DER & Sant Mammet (CoSTFur 2005) \\
\hline & & & Charneca de Lumiar (HEISSIG 1999) & MADE 1999) & Tarazona (GENTRY et al. 1999) \\
\hline & & & $\begin{array}{l}\text { Conrelas do Cavao (GÖHLICH 1999) } \\
\text { Córcoles (GöHLICH 1999) }\end{array}$ & $\begin{array}{l}\text { Quinta das Pedreiras } \\
\text { (GOHLICH 1999) }\end{array}$ & $\begin{array}{l}\text { Tarrabla V (CERDEÑo \& NIETO } \\
\text { 1995) }\end{array}$ \\
\hline & & & El Canyet (ForTElius 2003) & $\begin{array}{l}\text { Quinta do Narigao (VAN DER } \\
\text { MADE 1999) }\end{array}$ & Torrijos (CERDEÑo \& NIETO 1995) \\
\hline & & & & $\begin{array}{l}\text { Quinta Grande (GÖHLICH } \\
\text { 1999) }\end{array}$ & $\begin{array}{l}\text { Valdemoros la, } 1 \mathrm{~b} \text { (CERDEÑO \& } \\
\text { NIETO 1995) }\end{array}$ \\
\hline & & & & $\begin{array}{l}\text { La Retama (CERDEÑO \& } \\
\text { NIETO 1995) }\end{array}$ & Villafeliche (FORTELIUS 2003) \\
\hline & & & & $\begin{array}{l}\text { Monteaguado (FORTELJUS } \\
\text { 2003) }\end{array}$ & \\
\hline & MN3 & $\mathbf{n M}=\mathbf{9}$ & $\begin{array}{l}\text { Agreda (FORTELIUS 2003) } \\
\text { Colmenar (FORTELIUS 2003) } \\
\text { Costa Blanca (FORTELIUS 2003) }\end{array}$ & $\begin{array}{l}\text { Moratines (FORTELIUS 2003) } \\
\text { Horta dos Tripas (VAN DER } \\
\text { MADE 1999) } \\
\text { Molí Calopa (CERDEÑO \& } \\
\text { NIETO 1995) } \\
\text { Moratilla (MORALES \& } \\
\text { SORIA 1984) }\end{array}$ & $\begin{array}{l}\text { Nasa (MURELAGA et al. 2004) } \\
\text { San Andres de la Barca } \\
\text { (ForTELIUS 2003) } \\
\text { Tudela (FORTELIUS 2003) }\end{array}$ \\
\hline & MN2 & $\mathrm{nM}=\mathbf{8}$ & $\begin{array}{l}\text { Cabeza de la Junta (MURELAGA et al. } \\
\text { 2004) } \\
\text { Cetina de Aragon (CERDEÑo \& NIETO } \\
\text { 1995) } \\
\text { Le Encinilla (QUIRALTE \& MORALES } \\
\text { 2006) }\end{array}$ & $\begin{array}{l}\text { Loranca (CERDEÑo \& NIETO } \\
\text { 1995) } \\
\text { Moheda (FORTELIUS 2003) } \\
\text { Navarrete del Rio (GENTRY et } \\
\text { al. 1999) }\end{array}$ & $\begin{array}{l}\text { Remblar (MORALES \& SORIA } \\
\text { 1984) } \\
\text { Valquemado (CERDEÑo \& NIETO } \\
\text { 1995) }\end{array}$ \\
\hline & MN1 & $\mathbf{n} \mathbf{M}=\mathbf{0}$ & - & - & - \\
\hline & MP30 & $\mathbf{n M}=\mathbf{0}$ & - & - & - \\
\hline & MP29 & $\mathbf{n} \mathbf{M}=\mathbf{0}$ & - & - & - \\
\hline \multirow[t]{26}{*}{ France } & MN4 & $\mathbf{n M}=17$ & $\begin{array}{l}\text { Aérotrain (ANTOINE et al. 2000) } \\
\text { Artenay (ANTOINE et al. 2000) }\end{array}$ & $\begin{array}{l}\text { Bourg-Saint-Bernard } \\
\text { (FORTELIUS 2003) }\end{array}$ & $\begin{array}{l}\text { Pont Boutard (VAN DER MADE } \\
\text { 1999) }\end{array}$ \\
\hline & & & Auterive (FORTELIUS 2003) & Captieux (ForTELIUS 2003) & Pont du Manne (Heissig 1999) \\
\hline & & & Baigneaux (ANTOINE et al. 2000) & Chevilly (CERDEÑo 1993) & La Romieu (ANTOINE et al. 2000) \\
\hline & & & Le Baradieu (Costeur 2005) & Monbrun (FORTELIUS 2003) & La Sauvetat (FORTELIUS 2003) \\
\hline & & & Bézian (ANTOINE et al. 2000) & $\begin{array}{l}\text { Montréal-du-Gers (ANTOINE } \\
\text { et al. 2000) }\end{array}$ & $\begin{array}{l}\text { Vieux Collonges (FORTELIUS } \\
2003 \text { ) }\end{array}$ \\
\hline & & & & $\begin{array}{l}\text { Pellecahus (ANTOINE et al. } \\
2000 \text { ) }\end{array}$ & \\
\hline & MN3 & $\mathrm{nM}=15$ & Beaulieu (GINSBURG 2005) & Contres (FORTELIUS 2003) & Le Mazet (GOHLiCH 1999) \\
\hline & & & Les Beilleaux (ANTOINE et al. 2000) & Estrepouy (ANTOINE et al. & Navère (ANTOINE et al. 2000) \\
\hline & & & La Brosse (GINSBURG et al. 2000) & $2000)$ & Neuville-aux-Bois (ANTOINE et al. \\
\hline & & & Chilleurs-aux-Bois (ANTOINE et al. & Esvres (GINSBURG 1988) & 2000) \\
\hline & & & $2000)$ & Marsolan (ANTOINE et al. & Pontigné (GINSBURG \& BONNEAU \\
\hline & & & Chitenay (GINSBURG et al. 2000) & $2000)$ & 1995) \\
\hline & & & & $\begin{array}{l}\text { Mauvière (GINSBURG et al. } \\
2000 \text { ) }\end{array}$ & Ronville (coll. NMB) \\
\hline & MN2 & $\mathbf{n M}=\mathbf{8}$ & Barbotan-les-Thermes (GINSBURG et al. & Laugnac (DE BONIS 1973) & Saint-Gérand-le-Puy (HUGUENEY \\
\hline & & & 1991) & Moissac (CERDEÑo 1992) & 1997) \\
\hline & & & Chavroches (HUGUENEY 1997) & Montaigu-le-Blin & Selles-sur-Cher (HEISSIG 1999) \\
\hline & & & Gans (COSTEUR 2005) & (HUGUENEY 1997) & \\
\hline & MN1 & $\mathbf{n M}=\mathbf{9}$ & Cindré (HUGUENEY 1997) & Pauhliac (DE BONIS 1973) & Randan (DE BONIS 1973) \\
\hline & & & Gannat (HUGUENEY 1997) & Pechbonieu (CERDEÑO 1992) & Roche-Blanche-Gergovie \\
\hline & & & Métro Toulouse (ANTOINE et al. 2006) & Pyrimont-Challonges & (HUGUENEY et al. 1999) \\
\hline & & & & (HEISSIG 1999) & Saulcet (HuguENEY 1997) \\
\hline & MP30 & $\mathbf{n M}=\mathbf{4}$ & Coderet (HuguenEY 1997) & Peublanc (HUGUENEY 1997) & \\
\hline & & & Dieupentale (COSTEUR 2005) & Thézels (BRUNET et al. 1987) & \\
\hline & MP29 & $\mathrm{n} \mathbf{M}=\mathbf{5}$ & Chaufours (HUGUENEY 1997) & La Milloque (BRUNET et al. & Verneuil (HUGUENEY 1997) \\
\hline & & & Cournon (HUGUENEY 1997) & 1987) & \\
\hline & & & & $\begin{array}{l}\text { Mine des Roys (HUGUENEY } \\
\text { 1997) }\end{array}$ & \\
\hline
\end{tabular}


Table 4. (continued)

\begin{tabular}{|c|c|c|c|c|c|}
\hline \multirow[t]{6}{*}{ Switzerland } & $\begin{array}{l}\text { MN4 } \\
\text { MN3 }\end{array}$ & $\begin{array}{l}\mathrm{nM}=3 \\
\mathrm{nM}=6\end{array}$ & $\begin{array}{l}\text { Benken (BECKER 2003) } \\
\text { Bierkeller (KÄLIN 1997) } \\
\text { Brüttelen 1 (KÄLIN 1997) }\end{array}$ & $\begin{array}{l}\text { Glovelier (KÄLIN 1997) } \\
\text { Goldinger Tobel } 1 \text { (KÄLIN } \\
\text { 1997) } \\
\text { Cheyres Pra Bosset (BECKER } \\
\text { 2003) }\end{array}$ & $\begin{array}{l}\text { Tägernaustrasse (KÄLIN 1997) } \\
\text { La Molière (BECKER 2003) } \\
\text { Trub-Sältenbach (KÄLIN 1997) }\end{array}$ \\
\hline & MN2 & $\mathrm{nM}=16$ & $\begin{array}{l}\text { Béthusy (ENGESSER et al. 1993) } \\
\text { La Borde (ENGESSER et al. 1993) } \\
\text { La Chaux } 7 \text { (KÄLIN 1997) } \\
\text { Ch. des Falaises (ENGESSER et al. 1993) } \\
\text { Eschenbach (this study) } \\
\text { Haut du Calvaire (ENGESSER et al. } \\
\text { 1993) }\end{array}$ & $\begin{array}{l}\text { Maupas (ENGESSER et al. } \\
\text { 1993) } \\
\text { Morrens (ENGESSER et al. } \\
\text { 1993) } \\
\text { Moulin d'Assens (ENGESSER } \\
\text { et al. 1993) } \\
\text { Petites Roches (ENGESSER et } \\
\text { al. 1993) } \\
\text { Richemont (ENGESSER et al. } \\
\text { 1993) } \\
\text { Rovéréaz (ENGESSER et al. } \\
\text { 1993) }\end{array}$ & $\begin{array}{l}\text { La Solitude (ENGESSER et al. 1993) } \\
\text { Le Tunnel (ENGESSER et al. 1993) } \\
\text { Le Valentin (ENGESSER et al. } \\
\text { 1993) } \\
\text { Wallenried (BECKER et al. 2001) }\end{array}$ \\
\hline & MN1 & $\mathrm{nM}=4$ & $\begin{array}{l}\text { Engehalde (BECKER 2003) } \\
\text { Fornant 11, } 13 \text { (ENGESSER \& MÖDDEN } \\
\text { 1997) }\end{array}$ & $\begin{array}{l}\text { Wischberg (SCHAUB \& } \\
\text { HÜRZELER 1948) } \\
\text { Zürchermühle (VAN DER } \\
\text { MADE 1999) }\end{array}$ & \\
\hline & MP30 . & $\mathbf{n} \mathbf{M}=\mathbf{2}$ & Haslen (SCHAUB 1928) & $\begin{array}{l}\text { Küttigen (ENGESSER \& } \\
\text { MÖDDEN 1997) }\end{array}$ & \\
\hline & MP29 & $\mathrm{nM}=4$ & $\begin{array}{l}\text { Brochene Fluh 19/20 (ENGESSER \& } \\
\text { MÖDDEN 1997) }\end{array}$ & Rochette (BERGER 1998) & Rüf bei Schänis (BECKER 2003) \\
\hline & & & $\begin{array}{l}\text { Rickenbach (ENGESSER \& MÖDDEN } \\
\text { 1997) }\end{array}$ & & \\
\hline \multirow[t]{9}{*}{ Germany } & MN4 & $\mathrm{nM}=12$ & $\begin{array}{l}\text { Baggersee Freudenegg (SACH \& } \\
\text { HEIZMANN 2001) }\end{array}$ & $\begin{array}{l}\text { Grimmel fingen (SACH \& } \\
\text { HEIZMANN 2001) }\end{array}$ & $\begin{array}{l}\text { Langenau } 1,2 \text { (SACH \& } \\
\text { HEIZMANN 2001) }\end{array}$ \\
\hline & & & $\begin{array}{l}\text { Eggingen-Mittelhart } 3 \text { (SACH \& } \\
\text { HEIZMANN 2001) }\end{array}$ & $\begin{array}{l}\text { Günzburg (et GENTRY al. } \\
\text { 1999) }\end{array}$ & $\begin{array}{l}\text { Petersbuch (COSTEUR 2005) } \\
\text { Rauscheröd (GENTRY et al. 1999) }\end{array}$ \\
\hline & & & Engelwies (FORTELIUS 2003) & Illerkirchberg 1 (SACH \& & Ravenburg (FORTELIUS 2003) \\
\hline & & & Erkertshofen 2 (COSTEUR 2005) & HEIZMANN 2001) & \\
\hline & $\mathbf{M N 3}$ & $\mathbf{n M}=1$ & $\begin{array}{l}\text { Gerlenhofen (SACH \& HEIZMANN 2001) } \\
\text { Wintershof-West (AGULAR et al. 2003) }\end{array}$ & & \\
\hline & MN2 & $\mathrm{nM}=12$ & $\begin{array}{l}\text { Budenheim (TOBIEN 1980) } \\
\text { Eggingen (VON KÖNIGSWALD 1930) } \\
\text { Frankfurt (TOBIEN 1980) } \\
\text { Hessler (TOBIEN 1980) }\end{array}$ & $\begin{array}{l}\text { Hochheim-Flörshcim } \\
\text { (TOBIEN 1980) } \\
\text { Mischelsberg (DIETRICH } \\
\text { 1931) } \\
\text { Pappenheim (HEISSIG 1999) } \\
\text { Ulm (HEISSIG 1999) }\end{array}$ & $\begin{array}{l}\text { Ulm- Eselberg (VON KÖNIGSWALD } \\
\text { 1930) } \\
\text { Ulm-Liesberg (FORTELIUS 2003) } \\
\text { Ulm-Klinik (FORTELIUS 2003) } \\
\text { Ulm-Westtangente (FORTELIUS } \\
\text { 2003) }\end{array}$ \\
\hline & MN1 & $\mathbf{n} \mathbf{M}=\mathbf{8}$ & $\begin{array}{l}\text { Altheim-Breitenlauh (SACH \& } \\
\text { HEIZMANN 2001) } \\
\text { Finthen (TOBIEN 1980) }\end{array}$ & $\begin{array}{l}\text { Lautern } 2 \text { (COSTEUR 2005) } \\
\text { Oppenheim (TOBIEN 1980) } \\
\text { Tomerdingen } 2 \text { (HEISSIG } \\
\text { 1999) }\end{array}$ & $\begin{array}{l}\text { Treuchlingen } 2 \text { (COSTEUR 2005) } \\
\text { Weissenau (TOBIEN 1980) } \\
\text { Weissenburg } 6 \text { (COSTEUR 2005) }\end{array}$ \\
\hline & MP30 & $\mathrm{nM}=\mathbf{2}$ & Flörsheim (TOBIEN 1980) & $\begin{array}{l}\text { Rott bei Bonn (VON } \\
\text { KOENIGSWALD et al. 1992) }\end{array}$ & \\
\hline & MP29 & $\mathbf{n M}=\mathbf{1}$ & Herlingen (COSTEUR 2005) & & \\
\hline
\end{tabular}

Type species: Diaceratherium tomerdingense (DieTrich 1931).

Included species: Diaceratherium lamilloquense Michel 1983; Diaceratherium lemanense (POMEL 1853); Diaceratherium asphaltense (DEPÉRET \& DOUXAMI 1902); Diaceratherium tomerdingense DIETRICH 1931; Diaceratherium aginense (RÉPELIN 1917); Diaceratherium askazansorense KoRDIKOVA 2001; Diaceratherium aurelianense (Nouel 1866). Contrary to Lavocat (1951) and Heissig (1999), we do not use the genus Brachydiceratherium (LAVOCAT 1951 ) for the species D. lemanense.

\section{Diaceratherium lemanense (PoMEL 1853)}

\section{Synonymy list}

1834 Very large Lophiodon from Gannat - CUVIER: 414-417.

1839 Rhinoceros incisivus KaUP - DE BlaInVILle: pl. IX, X, XII.

1853 Acerotherium lemanense-POMEL: 77.

1853 Acerotherium gannatense-DUVERNOY: 51-70; pl. V; pl. VI, fig. 1, 2, 3, 10, 12, 18; pl. VII, fig. 2.

1853 Rhinoceros from Randan - DUVERNOY: 47-50; pl. VII, fig. 3 ; pl. VIII, fig. 5. 
Table 5. Categories of the different palaeoecological parameters used in this study.

\begin{tabular}{|c|c|c|}
\hline Body size & TDT & Shoulder height \\
\hline $\begin{array}{l}\text { small } \\
\text { medium-small } \\
\text { medium-large } \\
\text { large }\end{array}$ & $\begin{array}{c}<50 \\
50-60 \\
60-70 \\
>70\end{array}$ & $\begin{array}{c}<1.0 \mathrm{~m} \\
1.0-1.5 \mathrm{~m} \\
1.5 \mathrm{~m}-1.8 \mathrm{~m} \\
>1.8 \mathrm{~m}\end{array}$ \\
\hline Body mass & Weight & \\
\hline $\begin{array}{l}\text { small } \\
\text { medium-small } \\
\text { medium-large } \\
\text { large }\end{array}$ & $\begin{array}{c}<1000 \mathrm{~kg} \\
1000-1500 \mathrm{~kg} \\
1500-2000 \mathrm{~kg} \\
>2000 \mathrm{~kg}\end{array}$ & \\
\hline Slenderness & I-Gr (McIII) & \\
\hline $\begin{array}{l}\text { cursorial } \\
\text { mediportal } \\
\text { graviportal }\end{array}$ & $\begin{array}{l}<25 \\
25-30 \\
>30\end{array}$ & \\
\hline Diet & $\mathrm{I}-\mathrm{Hy}$ & $\begin{array}{l}\text { Feeding } \\
\text { category }\end{array}$ \\
\hline $\begin{array}{l}\text { brachyodont } \\
\text { mesodont } \\
\text { hypsodont }\end{array}$ & $\begin{array}{c}<80 \\
80-120 \\
>120\end{array}$ & $\begin{array}{l}\text { folivore } \\
\text { folivore } \\
\text { mixed feeder- } \\
\text { grazer }\end{array}$ \\
\hline Feeding behaviour & $\begin{array}{l}\text { Head holding (= feeding } \\
\text { posture) }\end{array}$ & $\begin{array}{l}\text { Herbivore } \\
\text { category }\end{array}$ \\
\hline $\begin{array}{l}\text { possibly specialized } \\
\text { in short vegetation } \\
\text { indiscriminate } \\
\text { specialized in tall } \\
\text { vegetation }\end{array}$ & $\begin{array}{l}\text { head posture down } \\
\text { head posture intermediate } \\
\text { head posture up }\end{array}$ & $\begin{array}{l}\text { regular } \\
\text { browser/grazer } \\
\text { regular browser } \\
\text { high browser }\end{array}$ \\
\hline
\end{tabular}

1900 Aceratherium lemanense POMEL - OsBORN: 243; fig. 8 b.

1911 Acerotherium lemanense POMEL - ROMAN: 58-64; pl. VII; pl. VIII, fig. 1, 1a, 1 b, 2, 2 a, 3.

1924 Aceratherium lemanense POMEL - ROMAN: 48-51; fig. 22-25.

1951 Diceratherium (Brachydiceratherium) lemanense POMEL - LAVOCAT: 113-115.

1973 Brachypotherium lemanense POMEL - DE BonIs: 123-128; fig. 26.3, 27.1, 29.2, 31.1, 32.2, 33.5 .

1982 Diaceratherium lemanense POMEL - GInsBURG et al.: 403-406.

1983 Diaceratherium lemanense POMEL - Michel: 135-147.

1987 Diaceratherium lemanense POMEL - BRUNET et al.: 64; pl. 1, fig. 1, 7, 8, 12 .

1999 Brachydiceratherium lemanense POMEL HeIssig: 181-182, 187.

Description: Skull (Fig. 3). The Eschenbach skull (NMSG-P2006/1), complete and very few deformed, belongs to a juvenile. The general outline of the skull is dolichocephalic (maximum zygomatic width/nasaloccipital length ratio $=0.43$ ). The nasal bones are fine and long. The premaxilla is also fine, very slightly longer than the nasals, and shows a marked upward vertical displacement at the anterior edge of the D1. The zygomatic arch is low in its anterior part, but slightly elevated with a flexure form, and weakly broader in its posterior part. The dorsal profile of the skull is mainly flat and characterised by a nasal tip pointing downwards, a slight dome at the nasal posterior part, a shallow frontal depression, a very slight occipital elevation, an acute occipital angle and an occipital side inclined backwards. The postglenoid and posttympanic apophyses are in contact, and the former is curved forwards. The back of the toothrow reaches the posterior half of the skull. The nasal notch is deep, U-shaped, marked by a small nick at the nasal tip and reaches the posterior edge of the P3 while the anterior border of the orbit is above the anterior edge of the M1. The minimal distance between the posterior edge of the nasal notch and the anterior border of the orbit is $53.0 \mathrm{~mm}$. In dorsal view, the nasal bones are not fused. No rough spots for nasal or frontal horns are identified. The postorbital constriction is strong, marked by very little separated fronto-parietal crests (minimum distance $=18.0 \mathrm{~mm}$ ). The biometrical dimensions of the Eschenbach skull are shown in Table 6.

Dentition (Fig. 4c). The anterior set of teeth is composed by the unique I1 and the back toothrow by the series D1-P2-P3-D4-M1-M2. The computed tomography points out the presence of the unerupted $\mathrm{P} 4$ and M3, but does not reveal any evidence for an unerupted P1. The paracone folding and the parastylic groove are well marked from the P3 to the M2. The lingual cingulum is strong and continuous on premolars. There are no enamel foldings on the crowns and no traces of cement. The crowns of the back teeth are rather high (mesodont state). The biometrical dimensions of the teeth and the hypsodonty index are given in Table 7.

Upper anterior teeth. The I1 are small with a low crown and a flattened elliptic shape of the crown cross section. The lingual face is larger than the labial one.

Upper milk teeth. The D1 has a subtriangular shape, a rounded ectoloph without marked foldings, a labial cingulum (well marked under the metacone) and a posterior cingulum delimiting a little postfossette. The D4 exhibits a quadrangular shape, a marked paracone folding, and well-developed parastyle and metastyle. 

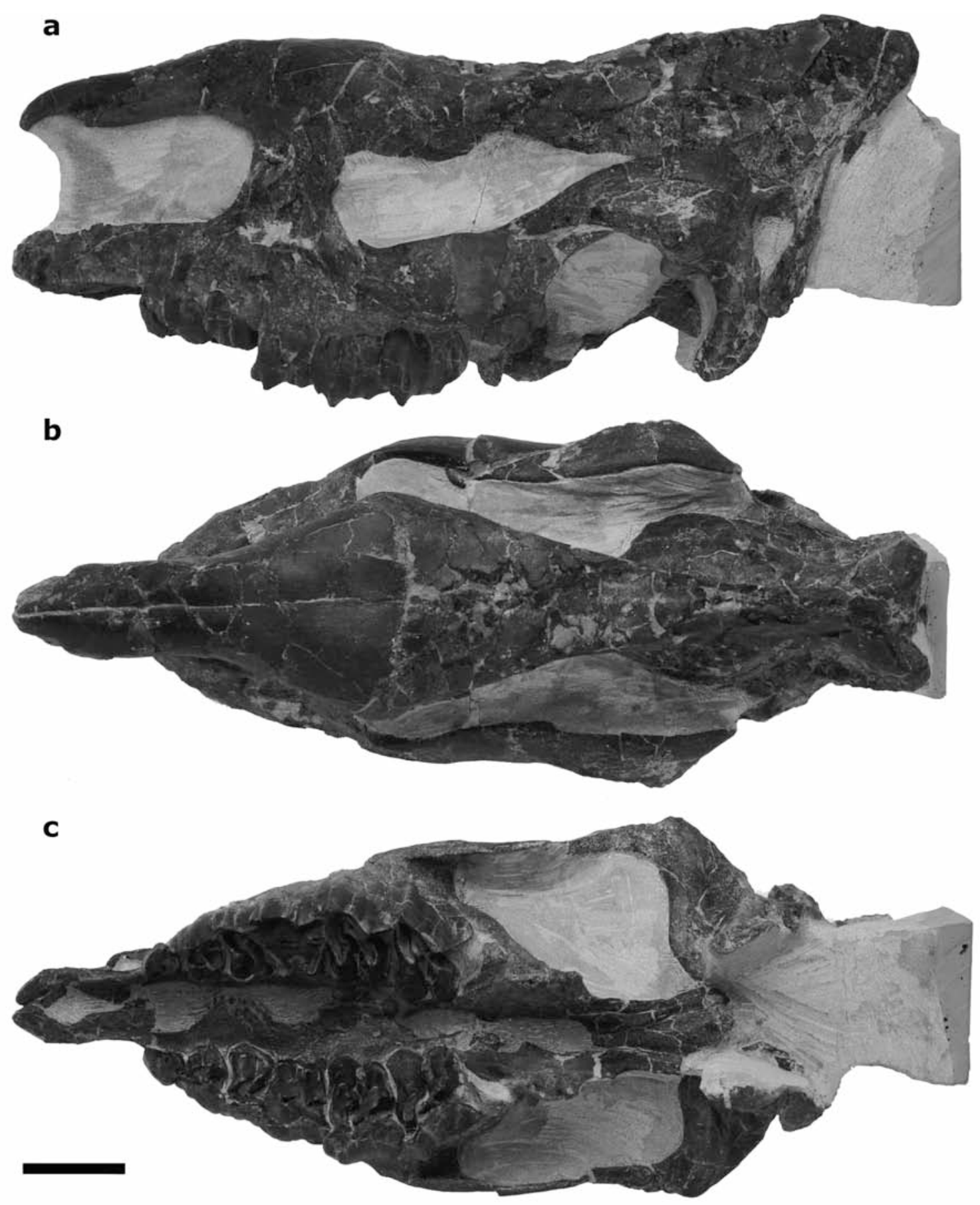

Fig. 3. Skull (NMSG-P2006/1) of Diaceratherium lemanense (PomeL, 1853) from the Aquitanian of Eschenbach (St. Gallen, Switzerland); a: left lateral view; b: dorsal view; c: palatine view. Scale bar: $5 \mathrm{~cm}$.

Upper premolars. The upper premolars are characterised by a rather flat ectoloph with a relatively weak paracone folding on the P2 but more marked on the P3. The outlines vary from trapezoidal for the P2 to rectangular for the P3. A crista and a crochet are developed and fused in depth, delimiting a pseudomedifossette. The metaloph is oblique, forming an angle at the starting of crochets. The protoloph and the 
Table 6. Biometrical dimensions of the Diaceratherium skulls. The data in italics are from the literature.

\begin{tabular}{|c|c|c|c|c|c|c|c|c|}
\hline Skull dimensions & $\begin{array}{l}\text { Diacerathe- } \\
\text { rium } \\
\text { lemanense } \\
\text { Gannat } \\
\text { RomAN } \\
1911\end{array}$ & $\begin{array}{l}D . \\
\text { lemanense } \\
\text { Eschen- } \\
\text { bach } \\
\text { NMSG- } \\
\text { P2006/1 }\end{array}$ & $\begin{array}{l}\text { D. cf. } \\
\text { lemanense } \\
\text { Engehalde } \\
\text { NMBE- } \\
\text { D3193 } \\
\text { OOSTER \& } \\
\text { FISCHER- } \\
\text { OOSTER } 1871\end{array}$ & $\begin{array}{l}\text { D. } \\
\text { asphaltense } \\
\text { Pyrimont- } \\
\text { Challonges } \\
\text { UCBL- } \\
\text { 212997 } \\
\text { DEPÉRET \& } \\
\text { DOUXAMI } \\
1902\end{array}$ & $\begin{array}{l}\text { D. } \\
\text { asphaltense } \\
\text { Wischberg } \\
\text { NMB-AS75 }\end{array}$ & $\begin{array}{l}D . \\
\text { asphaltense } \\
\text { Saulcet } \\
\text { NMB-SAU } \\
1662\end{array}$ & $\begin{array}{l}D . \\
\text { aginense } \\
\text { Laugnac } \\
\text { RÉPELIN } \\
1917\end{array}$ & $\begin{array}{l}D . \\
\text { aurelianense } \\
\text { Neuville-aux- } \\
\text { Bois } \\
\text { NOUEL } 1866 \\
\text { CERDEÑO } \\
1993\end{array}$ \\
\hline $\begin{array}{l}\text { Dist. occipital condyles- } \\
\text { premaxill }\end{array}$ & 554.0 & - & - & - & 640.0 & 630.0 & - & - \\
\hline $\begin{array}{l}\text { Dist. occipital condyles- } \\
\text { nasal }\end{array}$ & 539.0 & - & - & 625.0 & 595.0 & 610.0 & - & - \\
\hline $\begin{array}{l}\text { Dist. occipital crest- } \\
\text { nasal }\end{array}$ & 509.0 & 435.0 & 490.0 & $(590.0)$ & - & 555.0 & 545.0 & 495.0 \\
\hline L nasal notch & 167.5 & 122.0 & 175.0 & 193.0 & 170.0 & 178.0 & 180.0 & 160.0 \\
\hline $\mathrm{W}$ min. posterior skull & - & $(40.0)$ & 45.0 & $(70.0)$ & - & 42.0 & - & 169.0 \\
\hline $\begin{array}{l}\text { Dist. occipital crest-post- } \\
\text { orbital processus }\end{array}$ & - & 220.0 & - & 305.0 & - & - & - & 266.0 \\
\hline $\begin{array}{l}\text { Dist. occipital crest-sus- } \\
\text { orbital processus }\end{array}$ & - & 260.0 & - & 325.0 & - & 320.0 & 340.0 & - \\
\hline $\begin{array}{l}\text { Dist. occipital crest-ante- } \\
\text { orbital processus }\end{array}$ & 324.0 & 280.0 & - & 360.0 & - & 360.0 & - & - \\
\hline $\begin{array}{l}\text { Dist. nasal opening- } \\
\text { anterior border of orbit }\end{array}$ & 52.5 & 53.0 & 75.0 & 85.0 & 80.0 & 78.0 & - & 85.0 \\
\hline $\begin{array}{l}\text { Dist. posterior face M3- } \\
\text { condyle }\end{array}$ & 193.0 & - & - & 260.0 & 280.0 & 280.0 & - & - \\
\hline Dist. nasal-orbit & 220.5 & 170.0 & - & 278.0 & 250.0 & 245.0 & - & - \\
\hline W occipital crest & (71.5) & 66.0 & - & $(130.0)$ & $(180.0)$ & 150.0 & & 150.0 \\
\hline W mastoid apophyses & $(102.0)$ & 119.0 & - & 175.0 & - & 215.0 & - & 265.0 \\
\hline $\begin{array}{l}\text { Dist min. fronto-parietal } \\
\text { crests }\end{array}$ & $(10.0)$ & 18.0 & 34.0 & 17.0 & - & 29.0 & & 100 \\
\hline W post-orbital processus & 150.0 & 90.0 & $(134.0)$ & 140.0 & 110.0 & - & - & - \\
\hline W sus-orbital processus & 166.0 & 111.5 & $(138.0)$ & 135.0 & 140.0 & 165.0 & 170.0 & - \\
\hline W ante-orbital processus & 167.0 & 123.5 & $(144,0)$ & 140.0 & 160.0 & 175.0 & - & - \\
\hline $\begin{array}{l}\text { W max. zigomatic } \\
\text { arches }\end{array}$ & 217.0 & 186.5 & $(232.0)$ & $(290.0)$ & - & 380.0 & 340.0 & 350.0 \\
\hline W above nasal opening & 59.0 & 62.0 & - & 80.0 & $(75.0)$ & 100.0 & 105.0 & 96.0 \\
\hline $\begin{array}{l}\text { H occipital face (sup. } \\
\text { border of foramen) }\end{array}$ & - & - & - & $(75.0)$ & - & 130.0 & - & - \\
\hline $\begin{array}{l}\text { H occipital face (inf } \\
\text { border of foramen) }\end{array}$ & - & - & - & - & - & 185.0 & - & - \\
\hline H skull above $P 2$ & 191.0 & $(122.0)$ & 180.0 & 100.0 & - & 160.0 & - & - \\
\hline H skull above P4-M1 & 195.0 & $(140.0)$ & 225.0 & 95.0 & $(155.0)$ & 185.0 & - & - \\
\hline $\begin{array}{l}\text { H skull above middle of } \\
\text { M3 }\end{array}$ & 157.0 & $(131.0)$ & 225.0 & - & $(140.0)$ & 170.0 & - & - \\
\hline W palate between the $\mathrm{P} 2$ & - & 41.5 & - & 52.5 & - & 66.0 & - & - \\
\hline $\begin{array}{l}\text { W palate between the } \\
\mathrm{P} 4 / \mathrm{Ml}\end{array}$ & - & $(42.5)$ & - & 69.0 & - & 80.0 & - & - \\
\hline $\begin{array}{l}\text { W palate between the } \\
\text { M3 }\end{array}$ & - & - & - & 72.0 & - & 87.5 & - & - \\
\hline TD occipital foramen & - & - & - & 48.0 & $(35.0)$ & 45.0 & 60.0 & 53.5 \\
\hline TD occipital condyles & - & - & - & 114.5 & $(112.0)$ & 150.0 & - & 127.5 \\
\hline $\begin{array}{l}\text { Position of the nasal } \\
\text { opening }\end{array}$ & above $P 3$ & above P3/P4 & above $\mathrm{P3}$ & above $\mathrm{P3}$ & above P4 & above P3 & above P4 & above P3 \\
\hline $\begin{array}{l}\text { Position of the orbit } \\
\text { anterior border }\end{array}$ & above $M l$ & above Ml & above $\mathrm{P} 4 / \mathrm{M} 1$ & above Ml & above M2 & above $\mathrm{Ml}$ & $\begin{array}{l}\text { above } \\
M I / M 2\end{array}$ & above $M I$ \\
\hline
\end{tabular}

metaloph are parallel. A posterior cingulum is always present. The lingual cingulum is strong and continuous until the anterior face of the metaloph whilst the labial cingulum is absent. The P2 is semi-molariform with linked protocone and hypocone. The parastyle and metasyle are tapered and elongated in the axis of the ectoloph. The P3 is semi-molariform to molariform with a weak low lingual bridge between the protocone and the hypocone. The protoloph is slightly longer than the metaloph. The median valley (= medisinus) is S-shaped. Both postfossette and median valley are deep with the same depth. The parastyle is more developed than on the P2. 

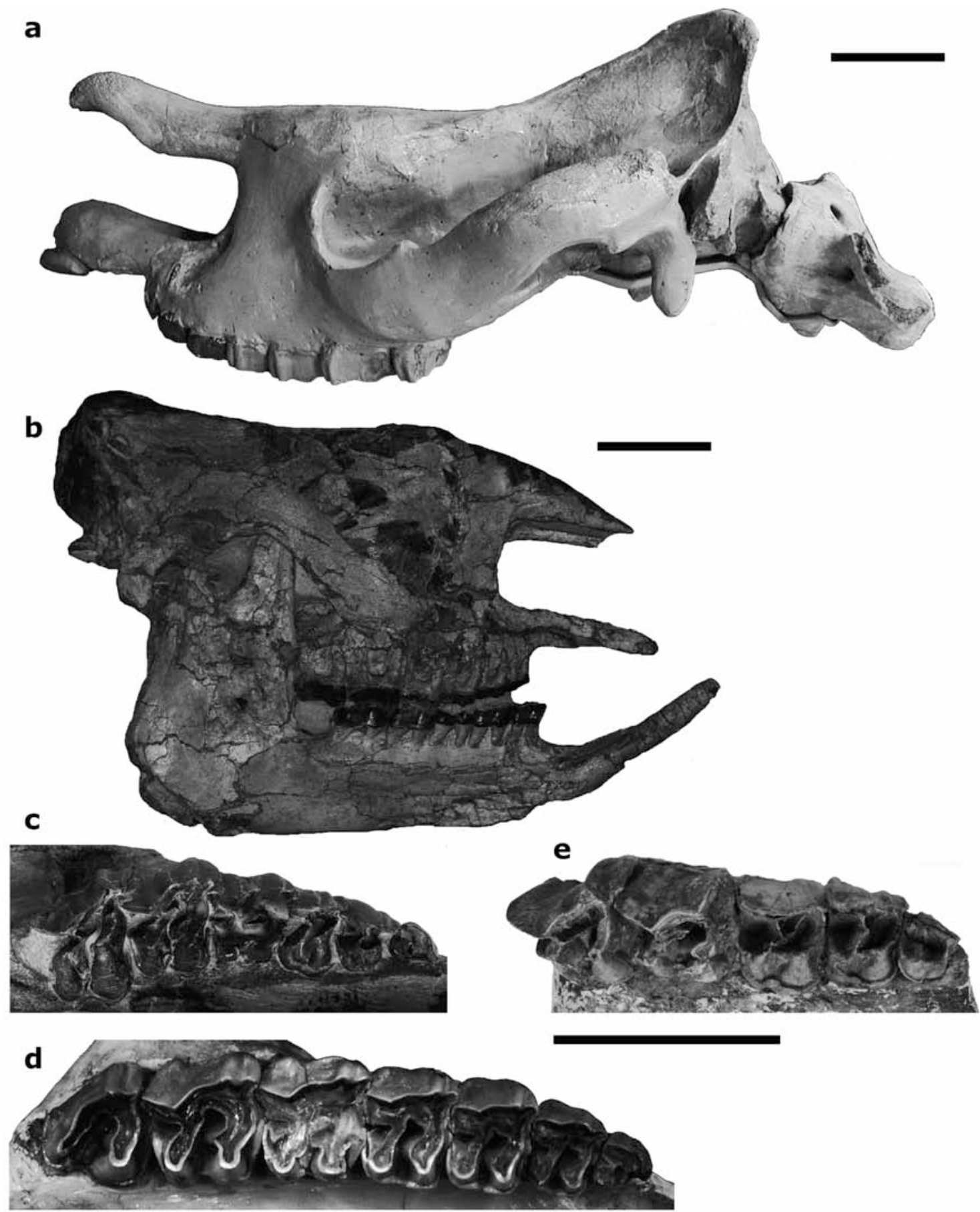

Fig. 4. Skulls and upper toothrows of European Aquitanian Diaceratherium. a: skull (NMB-Sau1662) of Diaceratherium asphaltense (DEPÉRET \& DouXAMI, 1902) from the Aquitanian of Saulcet (Allier, France), left lateral view; b: skull (NMBE-D3193) of Diaceratherium cf. lemanense (Pomel, 1853) from the Auitanian of Engehalde (Bern, Switzerland), right lateral view; c: upper right toothrow (D1-P2-3-D4-M1-2) from the skull (NMSG-P2006/1) of Diaceratherium lemanense (Pomel, 1853) from the Aquitanian of Eschenbach (St. Gallen, Switzerland), occlusal view; d: upper right toothrow (P1-M3) from the skull (NMB-SAU1662) of Diaceratherium asphaltense (DEPÉRET \& DouXAMI, 1902) from the Aquitanian of Saulcet (Allier, France), occlusal view; e: upper right toothrow (P2-M2) from the maxilla (MGL-3356) of Diaceratherium aginense (RÉPELIN, 1917) from the Aquitanian of Béthusy (Vaud, Switzerland), occlusal view. Scale bars: $10 \mathrm{~cm}$ 
Fig. 5. Diaceratherium lemanense (Pomel, 1853), Eschenbach (St. Gallen, Switzerland), Aquitanian; a, P3-D4 cast of the skull NMSGP2006/1, occlusal view; b, P3-4 digitized from computed tomography data of the skull NMSG- P2006/1, occlusal view; c, P3-4 cast from the computed tomography data of the skull NMSG-P2006/1. Scale bar: $1 \mathrm{~cm}$.

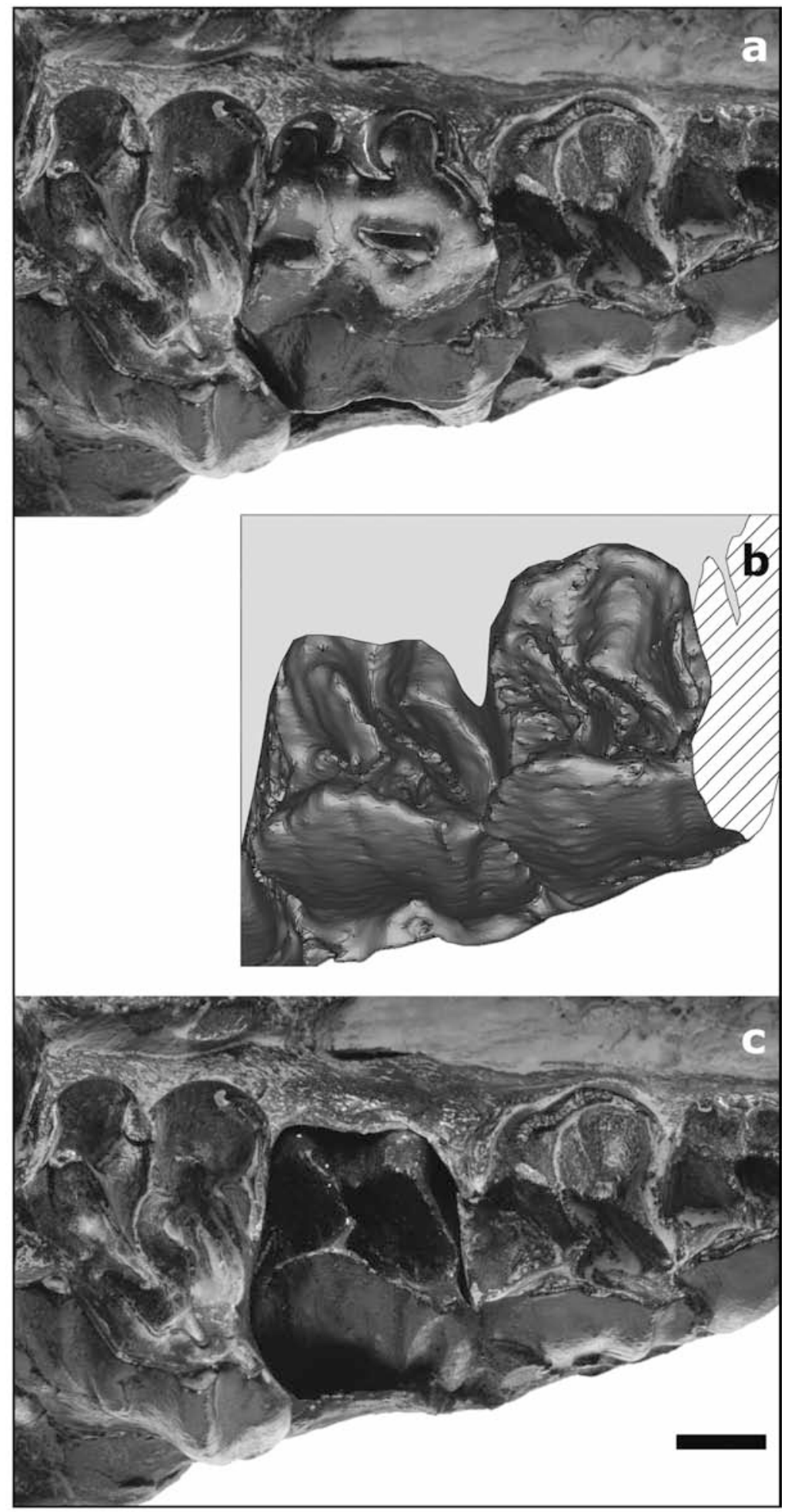

Upper molars. The M1 and M2 are subquadrangular. The crochet is always well developed and the crista only slightly marked on the M1. The antecrochet is thick on the M1, but is weakly developed in depth on the M2. The ectoloph profile is strongly oblique with respect to the axis of the toothrow, wing shaped in its posterior edge (in particular on the M2). The paracone folding is bulging, the parastyle and metastyle are 
Table 7. Biometrical dimensions and hypsodonty index of the upper back teeth of the Diaceratherium species. The data in italics are from the literature.

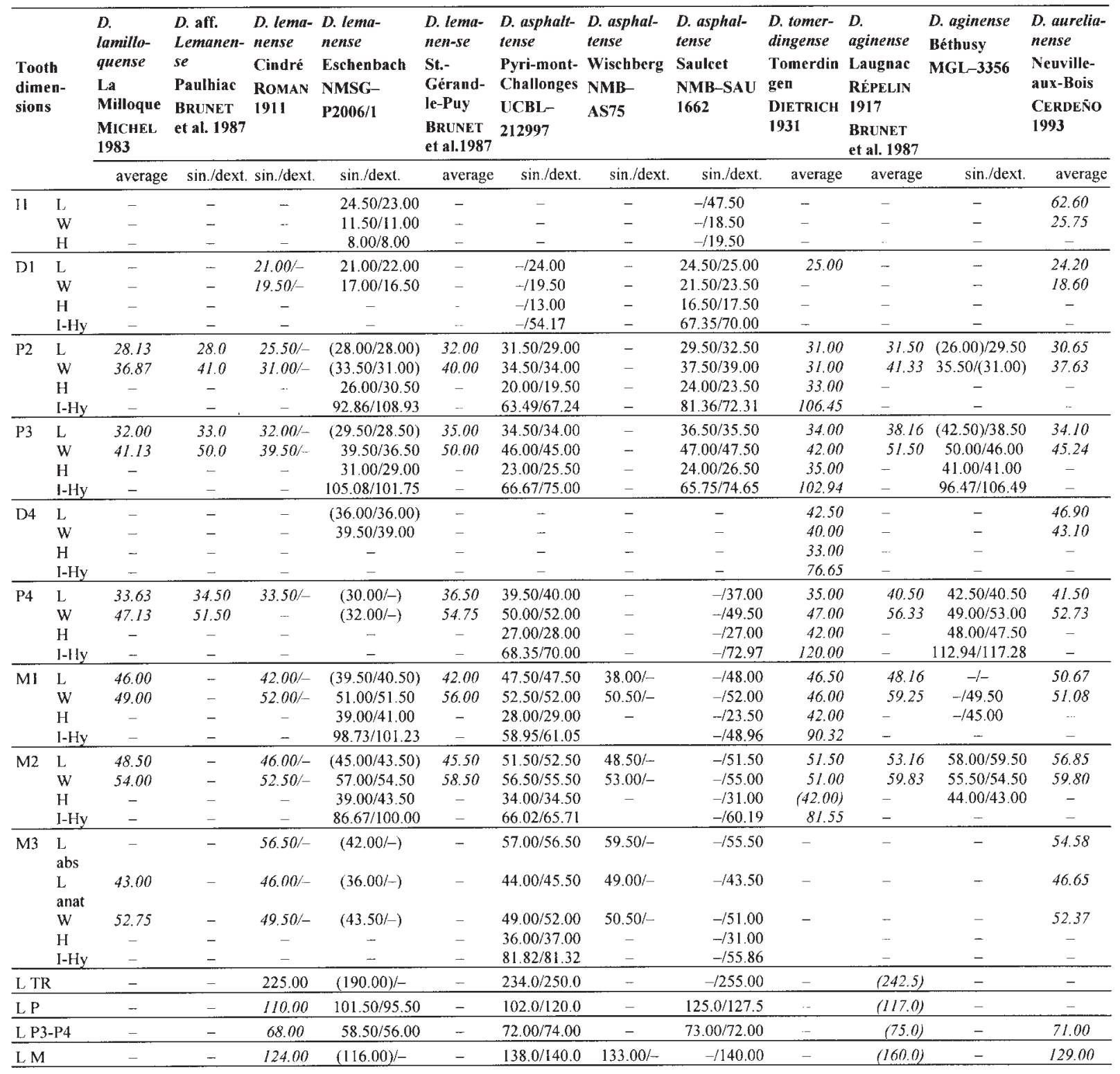

strongly elongated, and the mesostyle and metacone folding are very weakly marked. As on the premolars, the metaloph is oblique forming an angle at the starting of crochets when the protoloph and metaloph are parallel. The protocone constriction is well marked on the M1 but weaker on the M2, where it is only marked on the anterior face of the protoloph. The anterior face of the metaloph of the molars M1 and $\mathrm{M} 2$ is also constricted and the median valleys are deep, S-shaped and closed by secondary tubercles.
The postfossette shows the same depth than the median valley. The lingual cingulum is absent and a labial cingulum is only weakly marked at the base of the metacone folding on the M1.

\subsection{Tomography analyses, modelling and rapid prototyping (Fig. 5)}

The $\mathrm{P} 4$ digitized picture and cast are characterised by a quadrangular outline and a rather flat ectoloph with 
a marked paracone folding. Like the P3, the P4 cast is semi-molariform to molariform showing a weak and low lingual bridge between the protocone and the hypocone, fused crista and crochet in depth delimiting a pseudo-medifossette, a S-shaped median valley, and deep postfossette and median valley. The M3 digitized picture and cast show a triangular shape, a bulging paracone folding, a well-marked crochet and a lessdeveloped antecrochet.

\subsection{Palaeobiogeographical maps (Tab. 8, Fig. 6)}

The 178 large mammal localities are divided into 6 time intervals from MP29 to MN4, covering 7.4 million years (from 24.4 to $17.0 \mathrm{Ma}$ ). Each MP or MN biozone has 3 to 19 localities. During the latest Oligocene (MP29-30) the large mammal locality record seems weaker; it is mainly due to the lack of record in the Iberian Peninsula, but also because the MP29-30 time interval is very short. According to ENGESSER \& Mödden (1997), KempF et al. (1997) and SchmidtKITTLER et al. (1997), the biochronostratigraphic resolution of the MP29-30 time interval is of $0.3 \mathrm{Ma}$ per biozone. However, compared to the global record (MP29-MN4: $\mathrm{nM} / \mathrm{Ma}=\mathrm{ca} .24$ ), the distribution per million years is over the general mean. During the early Miocene (MN1-4), the distribution per million years is never less than 12. The number of localities dated to MN1 is relatively weak in Switzerland, because of a general uplift in the distal part of the Molasse Basin (sedimentary gap of the Jura Molasse) and the Alpine thrust of the proximal part (Subalpine Molasse) due to the Alpine orogenesis (BERGER et al. 2005); in MN3 and in MN4 a lower peak (nM/Ma $=12.4)$ and a higher peak $(\mathrm{nM} / \mathrm{Ma}=64)$ can be observed. These anomalies, strongly marked in Switzerland and Germany, are probably controlled by the transgressive-regressive phase of the perialpine Burdigalian Sea from south-western France to the Swiss Molasse Basin $(\mathrm{OMM}=$ Obere Meeresmolasse $=$ Upper Marine Molasse, MN2b-4; BERGER et al. 2005).

The richness of the Iberian Peninsula large mammal localities is particularly high in MN4 (nM/Ma =32), whereas no localities are recorded during the MP29-MN1 interval. The depositional systems in the internal basins of the Iberian block remain remarkably constant throughout the Tertiary. The sedimentary record of the Pyrenees and its bordering areas indicate that marine and subsequent fluvio-lacustrine sedimentation in the Pyrenean foreland basins stop-
Table 8. Distribution of large mammal localities per biozone $(\mathrm{nM})$, per million years $(\mathrm{nM} / \mathrm{Ma})$, and commonness (locality coverage) of Diaceratherium localities $(\% D$.) in Western Europe. $\mathrm{MB}=$ Mammal Biozones, $\mathrm{TI}=$ Time Interval in millions of years, IP $=$ Iberian Peninsula, FR = France, $\mathrm{SW}=$ Switzerland, GE $=$ Germany, WE $=$ Western Europe.

\begin{tabular}{|c|c|c|c|c|c|c|c|c|}
\hline MB & & MP29 & MP30 & MN1 & MN2 & MN3 & MN4 & $\begin{array}{l}\text { MP29- } \\
\text { MN4 }\end{array}$ \\
\hline TI & & 0 & 03 & 1 & 0 & 2.5 & 1.0 & 7.4 \\
\hline IP & $\begin{array}{c}\mathrm{nM} \\
\mathrm{nM} / \mathrm{Ma} \\
\% D .\end{array}$ & - & - & $\begin{array}{l}- \\
- \\
-\end{array}$ & $\begin{array}{r}8 \\
4.00 \\
12,50 \\
\end{array}$ & $\begin{array}{r}3.60 \\
22.22 \\
\end{array}$ & $\begin{array}{r}32 \\
32.00 \\
3.13\end{array}$ & $\begin{array}{r}49 \\
6.62 \\
8.16 \\
\end{array}$ \\
\hline FR & & 5 & $\begin{array}{r}4 \\
13.33 \\
25.00 \\
\end{array}$ & $\begin{array}{r}9 \\
6.92 \\
77.77 \\
\end{array}$ & $\begin{array}{r}8 \\
4.00 \\
62.50 \\
\end{array}$ & $\begin{array}{r}15 \\
6.00 \\
80.00 \\
\end{array}$ & & $\begin{array}{r}58 \\
7.84 \\
48.28 \\
\end{array}$ \\
\hline SW & $\begin{array}{c}\mathrm{nM} \\
\mathrm{nM} / \mathrm{Ma} \\
\% D .\end{array}$ & $\begin{array}{r}4 \\
13.33 \\
0 \\
\end{array}$ & $\begin{array}{r}2 \\
6.67 \\
0 \\
\end{array}$ & $\begin{array}{r}5.00 \\
50.00 \\
\end{array}$ & $\begin{array}{r}16 \\
8.00 \\
62.50 \\
\end{array}$ & $\begin{array}{r}6 \\
2.40 \\
50.00 \\
\end{array}$ & $\begin{array}{r}3 \\
3.00 \\
0 \\
\end{array}$ & $\begin{array}{r}35 \\
4.73 \\
42.86 \\
\end{array}$ \\
\hline G & $\begin{array}{c}\mathrm{nM} \\
\mathrm{nM} / \mathrm{Ma} \\
\% D \\
\end{array}$ & $\begin{array}{r}1 \\
3.33 \\
0 \\
\end{array}$ & $\begin{array}{r}2 \\
6.67 \\
50.00 \\
\end{array}$ & $\begin{array}{r}8 \\
6.15 \\
50.00 \\
\end{array}$ & $\begin{array}{r}12 \\
6.00 \\
25.00 \\
\end{array}$ & $\begin{array}{r}1 \\
0.40 \\
100 \\
\end{array}$ & $\begin{array}{r}12 \\
12.00 \\
8.33 \\
\end{array}$ & $\begin{array}{r}36 \\
4.86 \\
27.78 \\
\end{array}$ \\
\hline WE & $\begin{array}{c}\mathrm{nM} \\
\mathrm{nM} / \mathrm{Ma} \\
\% D .\end{array}$ & $\begin{array}{r}10 \\
33.33 \\
10.00 \\
\end{array}$ & $\begin{array}{r}8 \\
26.67 \\
25.00 \\
\end{array}$ & 61.90 & $\begin{array}{r}44 \\
22.00 \\
43.18 \\
\end{array}$ & $\begin{array}{r}31 \\
12.40 \\
58.06 \\
\end{array}$ & $\begin{array}{r}64 \\
64.00 \\
6.25 \\
\end{array}$ & $\begin{array}{r}178 \\
24.05 \\
32.02 \\
\end{array}$ \\
\hline
\end{tabular}

ped around the Eocene-Oligocene transition, but also during the middle Miocene (MeulenKamp \& SissingH 2003). These geological aspects could partially explain that the Iberian large mammal locality distribution during the Oligo-Miocene transition is recorded only since MN2 and is maximal in MN4.

The mean Diaceratherium commonness is rather high ( $\% D .>30 \%)$, in particular during the MN1-MN3 interval $(\% D .>50 \%)$. The weaker commonness during the MP29-30 interval is significant as well as the drastic decrease during MN4, because no sampling effects are detected into the Western European locality distribution. The occurrence of $D$. cf. aurelianense described in Loranca at the end of the MN2 biozone (CERdeÑo 1992, Cerdeño \& Nieto 1995 ) is assumed to be the FAD of the Spanish Diaceratherium, due to the very weak Diaceratherium commonness with respect to other countries such as France or Switzerland, whereas the large mammal locality distribution is in the Western Europe average. Moreover, the lack of Diaceratherium localities into the MP29-MN1 interval from the Iberian Peninsula has probably no influence on the European Diaceratherium commonness, because it does not count any large mammal localities. Finally, the disappearance of the diaceratheres just after the "Proboscidean Datum Event" is attested by the very high richness of the 


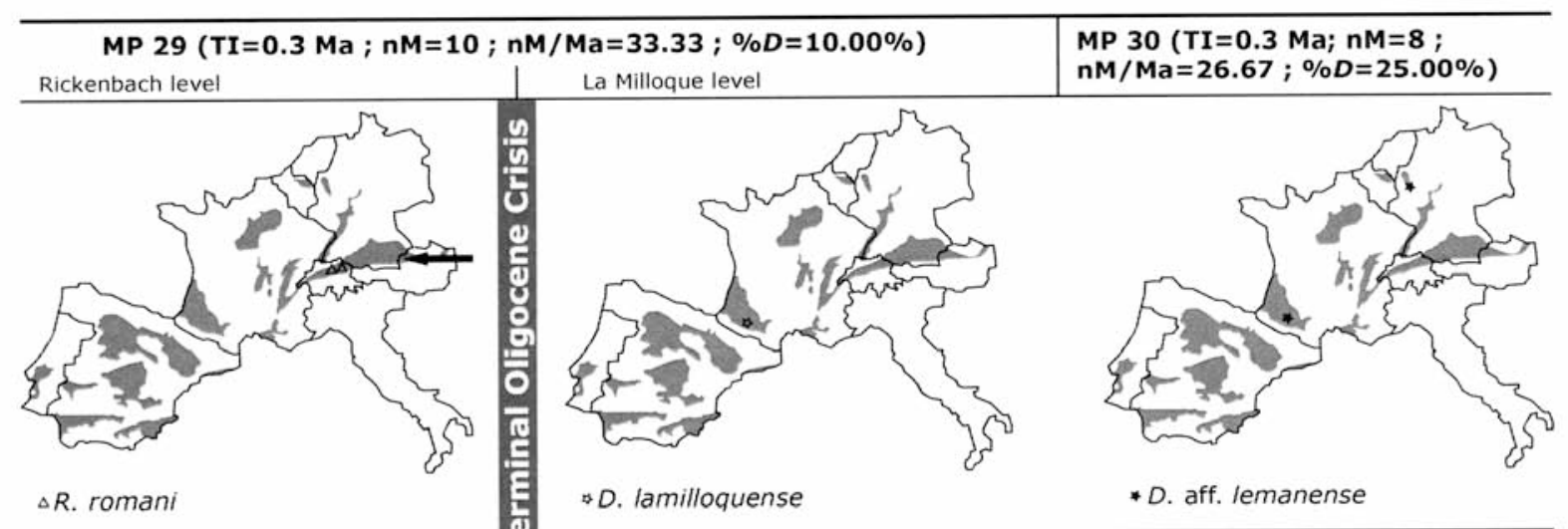

Typical Oligocene Fauna

Faunal renewal (phase 1)

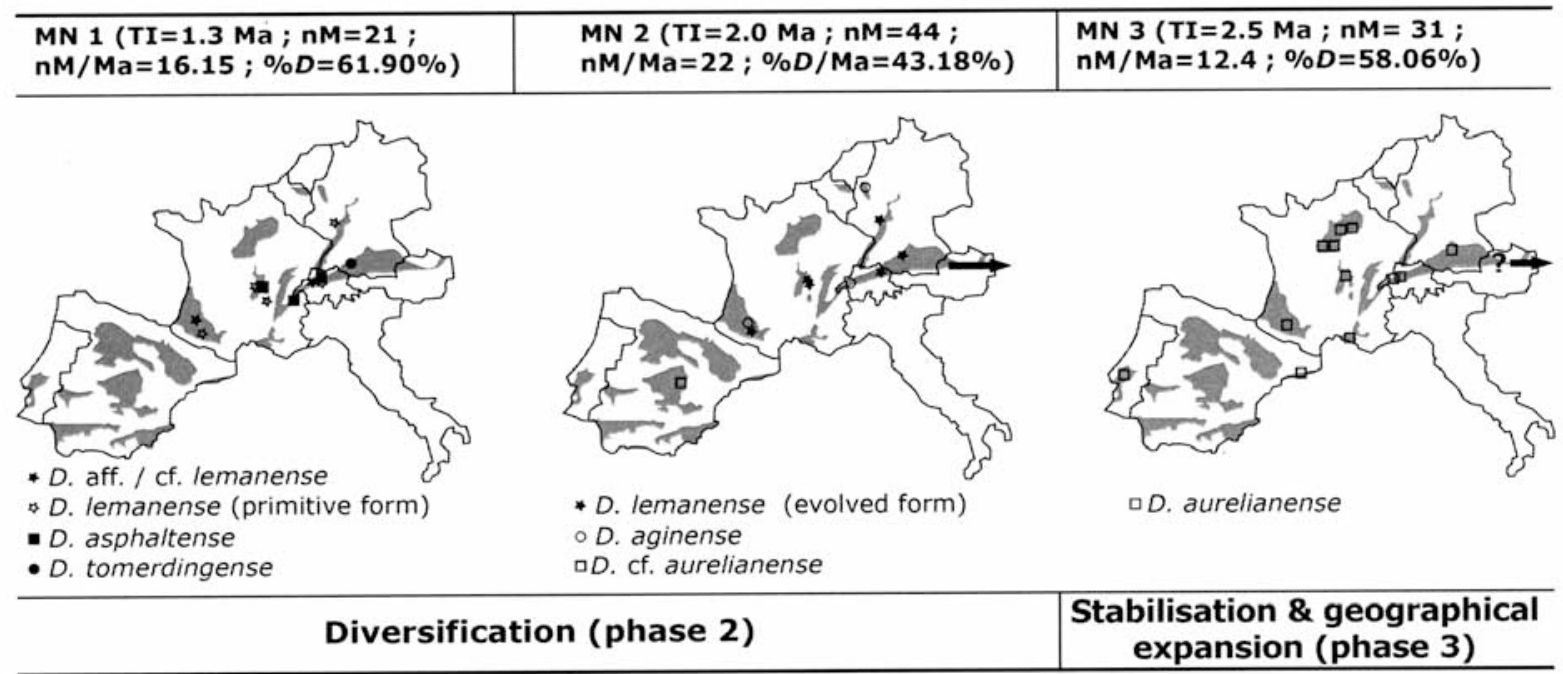

MN $4(\mathrm{TI}=1.0 \mathrm{Ma} ; \mathrm{nM}=64$;

$\mathrm{nM} / \mathrm{Ma}=64 ; \% D=6.25 \%$ )

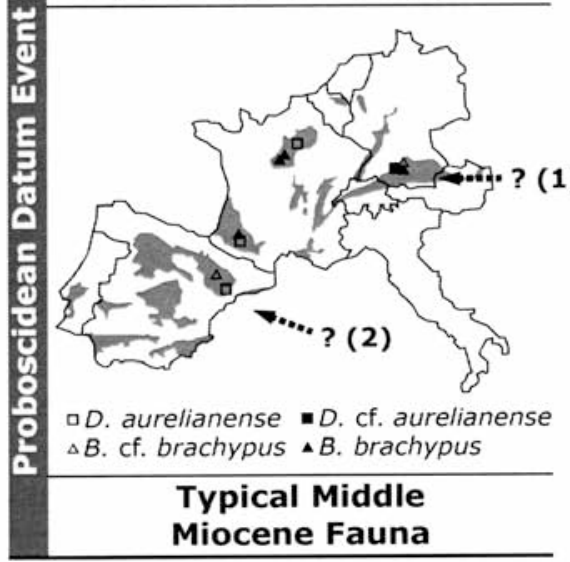

- Assumed immigration of diaceratheres (D. lamilloquense in La Milloque, France) from Asia (D. cf. lamilloquense in Nong Ya Plong. Thailand)

$\longrightarrow$ Assumed expansion of diaceratheres outside Europe (D. askazansorense in Askazansor, Southern Kazakhstan)

4.... ? Assumed immigration of brachypotheres by the normal European way $(\mathbf{1} ;$ B. brachypus in Chevilly, France) or by the Alpine Arch way ( $2 ; B$. cf. brachypus in Artesilla, Spain)

Fig. 6. Palaeobiogeographical distribution of the 57 European Diaceratherium localities (after the localities and the references reported in Table 3) compared with the last Ronzotherium romani and the first Brachypotherium brachypus localities. TI, time interval; nM, number of large mammal localities; $\mathbf{n M / M a , ~ n u m b e r ~ o f ~ l a r g e ~ m a m m a l ~ l o c a l i t i e s ~ p e r ~}$ million years; \% D., commonness (locality coverage) of Diaceratherium localities. Grey areas, European Tertiary basins. 


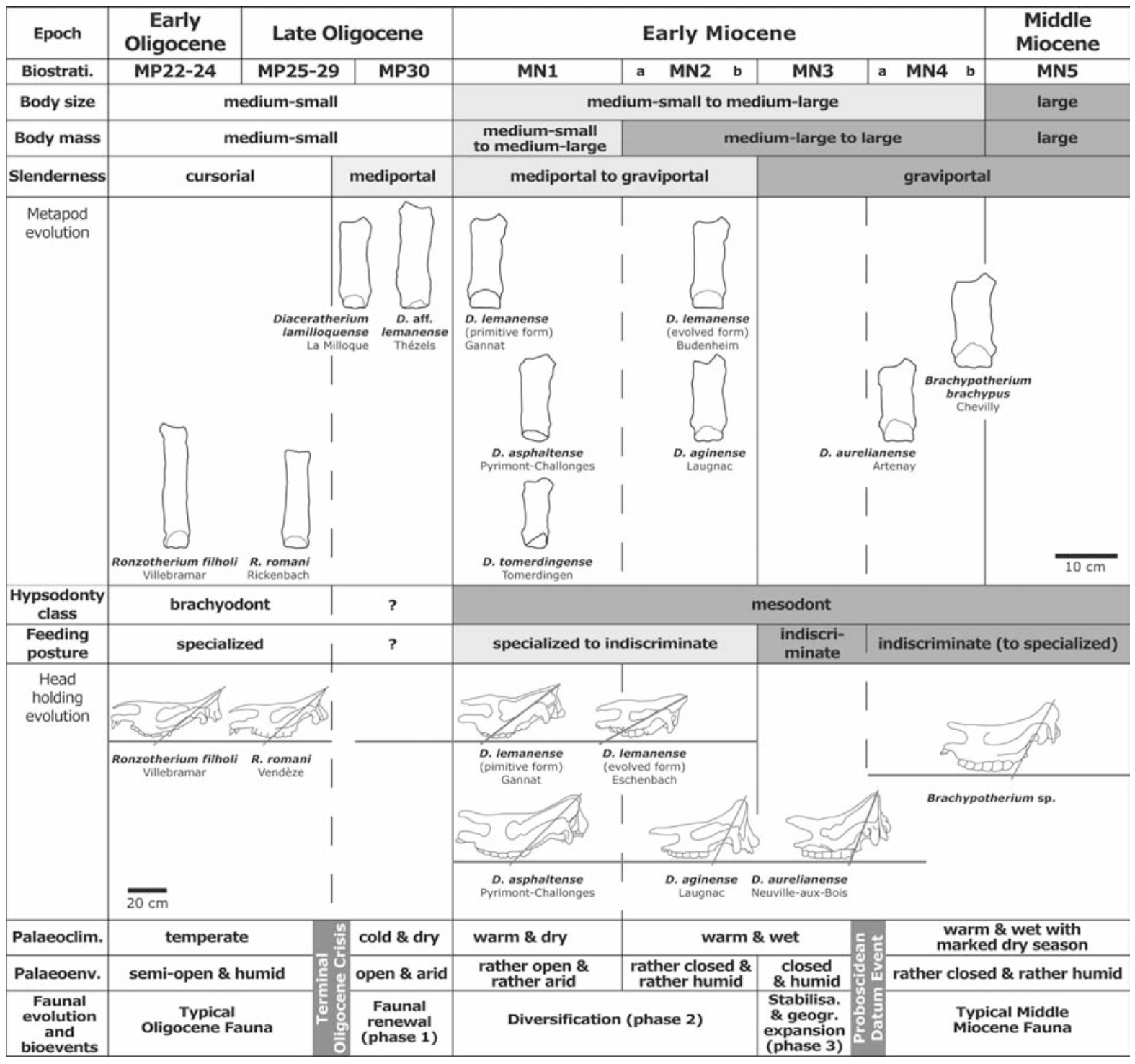

Fig. 7. Evolution of the palaeoecological parameters of the Diaceratherium species, compared with Ronzotherium filholi, $R$. romani and Brachypotherium brachypus (after the data reported in Tables 9 and 10). The fossil drawings are modified after Nouel 1866 (skull of Diaceratherium aurelianense, Neuville-aux-Bois), Depéret \& DouXAmi 1902 (McIII and skull of Diaceratherium asphaltense, Pyrimont-Challonges), RoMAn 1911 (skull of Diaceratherium lemanense, Gannat), RomAN 1924 (McIII of Diaceratherium lemanense, Budenheim), RÉPELIN 1917 (skull of Diaceratherium aginense, Laugnac), DIETRICH 1931 (McII of Diaceratherium tomerdingense, Tomerdingen), DE BonIS 1973 (McIII of Diaceratherium aginense, Laugnac), BRUNET 1979 (McIII and skull of Ronzotherium filholi, Villebramar; skull of Ronzotherium romani, Vendèze; McIII of Diaceratherium lamilloquense, La Milloque), Michel 1983 (McIII of Diaceratherium aff. lemanense, Thézels), Prothero et al. 1989 (skull of Brachypotherium sp.), CERdeño 1993 (McIII of Diaceratherium aurelianense, Artenay; McIII of Brachypotherium brachypus, Chevilly), BECKER 2003 (MtIII of Ronzotherium romani, Rickenbach) and unpublished photographs from the NMB (McIII of Diaceratherium lemanense, Gannat).

European large mammal locality distribution. For all these reasons the problematic issue of sampling is not really critical for the most part of the considered time interval. 
The overview of the Western European OligoMiocene palaeobiogeographical maps of the Diaceratherium localities underlines the latest Oligocene LAD of Ronzotherium (R. romani from Rickenbach and Rüfi bei Schänis in Switzerland; ENGESSER \& MöDden 1997, BeCKer 2003) and the FAD of Diaceratherium (D. lamilloquense from La Milloque in France; BRUNET et al. 1987). The earliest Miocene is mainly characterised by the diversification of the Diaceratherium species (D. lemanense, D. asphaltense, D. tomerdingense, D. aginense). At the end of MN2, the FAD of $D$. cf. aurelianense occurs in the Iberian Peninsula, corresponding to the first occurrence of diaceratheres in this area. Into the MN3 biozone, there is no more than one Diaceratherium species $(D$. aurelianense), but it is also the time interval of the greater commonness and geographical extension of the diaceratheres in Western Europe. Finally, the LAD of diaceratheres (Eggingen-Mittelhart 3 in Germany; SACH \& HeIZMAnN 2001) and the FAD (Artesilla in Spain; Cerdeño 1992, Cerdeño \& Nieto 1995) of the true brachypotheres in Europe mark the MN4 biozone pattern.

\subsection{Palaecological parameters (Tabs. 9 and 10;} Fig. 7)

The diacerathere palaeoecological parameters seem to follow the same pattern. We note ecological types close to ronzotheres within MP29-30, mixed ecological types within MN1-2 and close to brachypotheres within MN3-4.

Body size and mass. We can state a general pattern of increasing size and weight. Both parameters start with low values (compared to the early Miocene diaceratheres and brachypotheres) corresponding to Ronzotherium species and primitive diaceratheres of the latest Oligocene. During the early Miocene, particularly during the earliest Miocene (MN1-2), both parameters are mixed, regardless of the general increasing trend. From the late early Miocene the large sizes and forms become more and more exclusive.

Slenderness. This parameter, probably the more significant and characteristic, shows a progressive decreasing gracility. The ronzotheres are cursorial while the primitive diaceratheres are mediportal. The general pattern underlines mixed types within the earliest Miocene (mediportal to graviportal), but only the graviportal type exists since MN3.
Hypsodonty index and head holding. The crown height changes are only few marked. However, we can observe a slight progressive increase from brachyodont teeth (ronzotheres and primitive diaceratheres) to mesodont teeth (Miocene diaceratheres and brachypotheres). The head holding evolution is more changing. The ronzotheres belong to the low head holding type. The earliest Miocene diaceratheres show evidence of mixed head holdings (low and intermediate), whereas only the intermediate head holding is marked within MN3 by the last diacerathere representatives (D. aurelianense). The brachypotheres seems to show intermediate to low head holdings.

\section{Discussion}

\subsection{Taxonomic affinities}

Following GuÉRIN (1980) and CERDEÑO (1993), the Eschenbach specimen does not show the characteristics of the Brachypotherium genus, which generally presents larger dimensions, shorter nasals, broader postorbital constriction, as well as a lingual cingulum and a flat ectoloph profile (except a developed paracone folding) on the molars. The Ronzotherium genus also differs clearly from this specimen, showing an incomplete reduction of the anterior dentition (still composed of the I1 and I2) and a stronger occipital elevation (BRUNET 1979). Numerous morphological features of the Eschenbach skull (deep U-shaped nasal notch, long, fine and almost totally separated nasals, long and fine premaxilla, posterior elevation of the zygomatic arches) correspond to the descriptions of Diaceratherium skulls from the literature (POMEL 1853, DuvernoY 1853, Nouel 1866, Depéret \& Douxami 1902, RÉPELIN 1917, Dietrich 1931, Lavocat 1951, CERDEÑO 1993). The dental morphology (persistent D1, well marked parastylic groove on back teeth, strong lingual cingulum on premolars, developed antecrochet and crochet on molars, oblique and wing shaped ectoloph profile of the M1 and M2) is also typical for the Diaceratherium genus (DE BONIS 1973, MiCHEL 1983, Brunet et al. 1987, Ginsburg et al. 1981, 1991, Cerdeño 1993, ENGESSER et al. 1993).

The dorsal profile of $D$. aginense and D. aurelianense skulls differs from that of the specimen from Eschenbach by a strong occipital elevation, a vertical occipital side, a tendency to the brachyocephaly, postglenoid and posttympanic apophyses rather separated, and broader zygomatic arches (Nouel 1866, RoMAN 1911, RÉPELIN 1917, CERdEÑo 1993). The D. as- 
Table 9. Ecological data of Ronzotherium, Diaceratherium, Brachypotherium and living rhinoceroses, based on tooth and bone biometry and description. The *body masses are not based on the method of LEGENDRE (1989), but on the correlation regression of body mass on skull length (occipital condyles-premaxilla). D. = Diacerathium, B. = Brachypotherium, $R .=$ Rhinoceras, $C .=$ Ceratotherium .

\begin{tabular}{|c|c|c|c|c|c|c|c|c|c|}
\hline Taxon & Locality & $\begin{array}{l}\text { Data sources of osteologic and dentary } \\
\text { material }\end{array}$ & $\begin{array}{l}\text { Body } \\
\text { mass }\end{array}$ & TDT $(\mathrm{mm})$ & $\begin{array}{l}\text { I-Gr } \\
\text { (McII) }\end{array}$ & $\begin{array}{l}\text { I-Gr } \\
\text { (McLII) }\end{array}$ & $\begin{array}{l}\text { I-Gr } \\
\text { (MtIII) }\end{array}$ & 1-Iy & Head posture \\
\hline \multirow{2}{*}{$\begin{array}{l}\text { Ronzotherism } \\
\text { filholi }\end{array}$} & Villebramar & Brunet 1979, Emery 2004 , direct observation & $* 1075 \mathrm{~kg}$ & 54.00 & 20.45 & 20.40 & - & 64.0 & down \\
\hline & Bumbach & Becker 2003 & - & - & 26.10 & - & - & 82.1 & - \\
\hline \multirow{2}{*}{$\begin{array}{l}\text { Ronzontherium } \\
\text { romani }\end{array}$} & Vendèze & Brunet 1979 & $* 780 \mathrm{~kg}$ & - & - & - & - & - & down \\
\hline & Rickenbach & $\begin{array}{l}\text { Becker 2003, Emery 2004, Emery et al. } 2007 \text {, } \\
\text { direct observation }\end{array}$ & - & 51.00 & - & - & 23.65 & 63.5 & - \\
\hline \multirow{3}{*}{$\begin{array}{l}\text { Diaceratherium } \\
\text { lamilloquense } \\
\text { Diaceratherium } \\
\text { aff. Iemanense }\end{array}$} & La Milloque & Michel 1983 & $1043 \mathrm{~kg}$ & - & - & 28.10 & - & $\cdots$ & - \\
\hline & Thezzels & Michel 1983 & $1375 \mathrm{~kg}$ & 60.00 & - & 28.05 & - & - & - \\
\hline & Pauthiac & Michel 1983 & $1342 \mathrm{~kg}$ & 52.75 & - & 29.60 & - & - & - \\
\hline \multirow{5}{*}{$\begin{array}{l}\text { Diaceratherium } \\
\text { cf. Icmanense } \\
\text { Diaccratherium } \\
\text { lemanense }\end{array}$} & Engehalde & direct observation & $1202 \mathrm{~kg}$ & - & & - & - & - & down \\
\hline & Gannat (prim form) & Roman 1911, Michel 1983, direct observation & - & 03.50 & - & - & 30.40 & - & down (-intermediate) \\
\hline & Wischberg & direct observation & $1430 \mathrm{~kg}$ & $\$ 4.50$ & - & - & - & - & - \\
\hline & Eschenbach (ev. form) & direct observation & - & -- & - & - & - & 108.93 & down \\
\hline & Budenheim (ev, form) & Roman 1924 & - & 54.00 & + & 29.93 & 27.78 & - & - \\
\hline \multirow{3}{*}{$\begin{array}{l}\text { Diaceratherium } \\
\text { asphahense }\end{array}$} & Pyrimont-Challonges & Deperet \& Douxami 1902, direct observation & $1779 \mathrm{~kg}$ & - & 2550 & 33.10 & 31.90 & 81.32 & intermediate \\
\hline & $\begin{array}{l}\text { Saulcet } \\
\text { Wischberg }\end{array}$ & direct observation & - & - & - & - & - & 74.65 & intermediate \\
\hline & Wischberg & direct observation & $1790 \mathrm{~kg}$ & 61.00 & - & - & - & - & intermediate \\
\hline $\begin{array}{l}\text { Diaceratherium } \\
\text { tomerdingense }\end{array}$ & Tomerdingen 2 & Dietrich 1931 & $1779 \mathrm{~kg}$ & - & 34.80 & - & - & 120.00 & \\
\hline \multirow{3}{*}{$\begin{array}{l}\text { Diaceratherium } \\
\text { aginense }\end{array}$} & Betthusy & Engesser et al. 1993 & $2141 \mathrm{~kg}$ & - & - & - & - & 117.28 & \\
\hline & Moulin d'Assens & Engesser et al. 1993 & $2278 \mathrm{~kg}$ & - & - & - & - & -- & - \\
\hline & Laugnac & Repelin 1917, de Bonis 1973. Michel 198.3 & $1689 \mathrm{~kg}$ & 54.00 & 31.00 & 32.75 & - & - & intermediate \\
\hline \multirow{7}{*}{$\begin{array}{l}\text { Diaceratherium } \\
\text { aurelianense }\end{array}$} & Brüttelen 1 & Becker 2003 & - & 51.50 & - & - & - & - & - \\
\hline & Cheyres Pra Bosset & Becker 2003 & & - & - & -. & - & 80.15 & - \\
\hline & Beaulieu & Agutlar et al 2003 & $1712 \mathrm{~kg}$ & 55.80 & - & - & - & - & - \\
\hline & Moli Calopa & Santafe Llopsis 1978 & - & - & - & 30.77 & - & 80.41 & - \\
\hline & Neuville-aux-Bois & Nouel 1866, Mayet 1908, Cerdeño 1993 & $1531 \mathrm{~kg}$ & 50.30 & 30.76 & 34.73 & 36.44 & - & intermediate (-up) \\
\hline & Chilleurs-aux-Bois & Cerdeño 1993 & $1665 \mathrm{~kg}$ & 48.00 & 29.47 & - & - &.- & - \\
\hline & Artenay & Cerdeño 1993 & $1712 \mathrm{~kg}$ & 56.70 & 33.10 & 36.60 & 41.03 & & - \\
\hline \multirow{8}{*}{$\begin{array}{l}\text { Brachypotheriumt } \\
\text { brachypus }\end{array}$} & Chevilly & Cerdeño 1993 & - & 73.95 & - & 37.88 & - & - & - \\
\hline & Bajgneaux & Cerdeño 1993 & - & 70.00 & - & 32.10 & 35.75 & - & - \\
\hline & Beaugency & Cerdeño 1993 & $2767 \mathrm{~kg}$ & - & - & - & - & - & - \\
\hline & La Romieu & Cerdeño 1993 & $2155 \mathrm{~kg}$ & 73.00 & 24.74 & 29.71 & 34.65 & - & - \\
\hline & Savigné & Cerdeño 1993 & - & 67.60 & - & - & - & - & - \\
\hline & $\begin{array}{l}\text { Pontlevoy } \\
\text { Malartic }\end{array}$ & Cerdeño 1993 & $2333 \mathrm{~kg}$ & 68.00 & $\cdots$ & - & - & - & - \\
\hline & $\begin{array}{l}\text { Malartic } \\
\text { Montchaibeux }\end{array}$ & Cerdeño 1993 & $2490 \mathrm{~kg}$ & 74.45 & 30.86 & 36.75 & 38.75 & - & intermediate (-down) \\
\hline & Montchaibeux & Becker 2003 & - & 62.50 & - & - & - & - & - \\
\hline $\begin{array}{l}\text { Brachypotherium } \\
\text { perimense }\end{array}$ & Nikkiwalanala (PK) & Heissig 1972 & - & - & - & - & 38.02 & - & intermediate \\
\hline \multirow{2}{*}{$\begin{array}{l}\text { Brachypotherium } \\
\text { sp. }\end{array}$} & - & Guérin 1980 & - & - & - & - & - & 97.25 & - \\
\hline & - & Prothero et al. 1989 & - & - & -- & - & - & - & intermediate \\
\hline $\begin{array}{l}\text { Ceratotheritum } \\
\text { simum }\end{array}$ & - & Guèrin 1980 & $2423 \mathrm{~kg}$ & 6485 & 23.15 & 30.01 & 28.03 & 195.32 & down \\
\hline \multicolumn{2}{|l|}{$\begin{array}{l}\text { Diceros } \\
\text { bicornis }\end{array}$} & Guerin 1980 & $* 1075 \mathrm{~kg}$ & 6205 & 23.82 & 28.0 & 27.07 & 139,18 & intermediate \\
\hline Rhinoceres & - & Guérin 1980 & $2166 \mathrm{~kg}$ & 7500 & 23.07 & 28.21 & 27.34 & 130.29 & up \\
\hline \multicolumn{10}{|l|}{$\begin{array}{l}\text { Rhinoccros } \\
\text { unicornis }\end{array}$} \\
\hline $\begin{array}{l}\text { Rhinoceros } \\
\text { sontaicus }\end{array}$ & - & Guérin 1980 & $1810 \mathrm{~kg}$ & 6120 & 26.28 & 33.63 & 34.67 & 11517 & up \\
\hline $\begin{array}{l}\text { Diccrorhinus } \\
\text { sumatrensis }\end{array}$ & - & Guérin 1980 & $1190 \mathrm{~kg}$ & 5530 & 23.98 & 27.03 & 26.78 & 120.82 & intermediate \\
\hline
\end{tabular}

phaltense skull shows a higher occipital crest, a rather vertical occipital side, separated postglenoid and posttympanic apophyses, and significantly broader zygomatic arches (DEPÉRET \& DouXAMi 1902). In addition, its nasal tip is slightly elevated, forming a small convexity with a double lateral rough tubercle, separated by unfused nasals. These bumps are particularly well marked on the skulls of the specimens 
Table 10. Overview of the different ecological parameters of Ronzotherium, Diaceratherium, Brachypotherium and living rhinoceroses (after BALES 1996, NOWAK 1999, CHRISTIANSEN 2002, http://animaldiversity.ummz.umich.edu/site/index.html, http://www.rhinos-irf.org; see also Tab. 9 for data sources of osteological and dental material). The * body mass parameters are not supported by method of LEGENDRE (1989), but by the correlation regression of body mass on skull length (occipital condyles-premaxilla).

\begin{tabular}{|c|c|c|c|c|c|c|c|c|c|}
\hline & Taxon & $\begin{array}{l}\text { Body mass from } \\
\text { literature } \\
\text { (kg) }\end{array}$ & $\begin{array}{l}\text { Body mass from } \\
\text { the method of } \\
\text { Legendre } 1989\end{array}$ & $\begin{array}{l}\text { Shoulder height } \\
\text { from literature } \\
\text { (cm) }\end{array}$ & $\begin{array}{l}\text { Body size } \\
\text { based on the } \\
\text { TDT }\end{array}$ & $\begin{array}{l}\text { Slenderness } \\
\text { based on the } \\
\text { I-Gr }\end{array}$ & $\begin{array}{l}\text { Dietary regime } \\
\text { and } \\
\text { hypsodonty } \\
\text { class }\end{array}$ & $\begin{array}{l}\text { Feeding behaviour } \\
\text { based on head holding } \\
\text { (= feeding posture) }\end{array}$ & $\begin{array}{l}\text { Diet and environment } \\
\text { based on extant } \\
\text { rhinoceroses }\end{array}$ \\
\hline 1 & $\begin{array}{l}\text { Rhinoceros } \\
\text { unisornis }\end{array}$ & $1800-2700$ & large & $180-200$ & large & mediportal & GrBr-H & $\begin{array}{l}\text { specialized in tall } \\
\text { vegetation }\end{array}$ & $\begin{array}{l}\text { mixed feeder living in } \\
\text { floodplain with open } \\
\text { high-grassland. } \\
\text { bushland. swamp and } \\
\text { river areas }\end{array}$ \\
\hline 2 & $\begin{array}{l}\text { Cerototherium } \\
\text { simum }\end{array}$ & $1800-2700$ & large & $150-180$ & medium-large & graviportal & $\mathrm{Gr}-\mathrm{H}$ & $\begin{array}{l}\text { specialized in short } \\
\text { vegetation }\end{array}$ & $\begin{array}{l}\text { roughage and dry } \\
\text { region grazer living in } \\
\text { flat open grassland with } \\
\text { isolated trees }\end{array}$ \\
\hline \multirow[t]{6}{*}{3} & $\begin{array}{l}\text { Rhinoceros } \\
\text { sondaicus }\end{array}$ & $900-2300$ & medium-large & 150.170 & medium-large & graviportal & $\mathrm{Br}-\mathrm{M}$ & $\begin{array}{l}\text { specialized in tall } \\
\text { vegetation }\end{array}$ & \multirow{6}{*}{$\begin{array}{l}\text { high browser living in } \\
\text { dense to slightly open } \\
\text { forest close to water } \\
\text { beds or swamps }\end{array}$} \\
\hline & $\begin{array}{l}\text { Brokhypeshorinm } \\
\text { hrowhyms }\end{array}$ & - & large & - & $\begin{array}{l}\text { medium-large } \\
\text { to large }\end{array}$ & graviportal & $\mathrm{Br}-\mathrm{M}$ & $\begin{array}{l}\text { indiscriminate (to } \\
\text { possibly specialized in } \\
\text { short vegetation) }\end{array}$ & \\
\hline & $\begin{array}{l}\text { Diaceratherinm } \\
\text { ameliamense' }\end{array}$ & - & medium-large & - & medium-small & graviportal & $\mathrm{Br}-\mathrm{M}$ & $\begin{array}{l}\text { indiscriminate (to } \\
\text { possibly in tall } \\
\text { vegetation) }\end{array}$ & \\
\hline & $\begin{array}{l}\text { Dicherwherimm } \\
\text { agsinenses }\end{array}$ & - & latge & - & medium-small & graviportal & $\mathrm{Br}-\mathrm{M}$ & $\begin{array}{l}\text { indiscriminate (to } \\
\text { specialized in tall } \\
\text { vegetation) }\end{array}$ & \\
\hline & $\begin{array}{l}\text { Diaceratherium } \\
\text { asphallomse }\end{array}$ & - & medium-large & - & medium-large & graviportal & $\mathrm{Br}-\mathrm{M}$ & indiscriminate & \\
\hline & 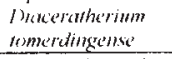 & - & medium-large & - & . & graviportal & Br-M & - & \\
\hline \multirow[t]{3}{*}{4} & Diceren bicormis & $800-1400$ & $\begin{array}{l}{ }^{*} \text { small to } \\
\text { medium-small }\end{array}$ & $140-170$ & medium-large & mediportal & $\mathrm{Br}-\mathrm{H}$ & indiscriminate & \multirow{3}{*}{$\begin{array}{l}\text { regular browser living } \\
\text { in bushland, in the } \\
\text { transitional zone } \\
\text { between forest and } \\
\text { grassland }\end{array}$} \\
\hline & $\begin{array}{l}\text { 1). lemoriches } \\
\text { (evolved form) }\end{array}$ & - & medium-small & - & medium-small & mediportal & $\mathrm{Br}-\mathrm{M}$ & $\begin{array}{l}\text { possibly specialized in } \\
\text { short vegetation }\end{array}$ & \\
\hline & $\begin{array}{l}\text { 1). lemanensi } \\
\text { (primitive form) }\end{array}$ & - & medium-small & - & medium-large & mediportal & $\mathrm{Br}-?$ & $\begin{array}{l}\text { possibly specialized in } \\
\text { short vegetation (to } \\
\text { indiscriminate) }\end{array}$ & \\
\hline \multirow[t]{2}{*}{5} & $\begin{array}{l}\text { Dicerorhinus } \\
\text { sumatrensis }\end{array}$ & $600-950$ & medium-small & $100+150$ & medium-small & mediportal & $\mathrm{Br}-\mathrm{H}$ & indiscriminate & \multirow{2}{*}{$\begin{array}{l}\text { regular browser living } \\
\text { in rainforest close to } \\
\text { water beds or swamps }\end{array}$} \\
\hline & $\begin{array}{l}\text { Decreratherium } \\
\text { lemilloguremse }\end{array}$ & $\cdots$ & medium-small & - & - & mediportal & $\mathrm{Br}-?$ & -- & \\
\hline \multirow[t]{2}{*}{6} & $\begin{array}{l}\text { Ronzothe'rwm } \\
\text { romami }\end{array}$ & - & *small & - & medium-smal] & cursorial & $\mathrm{Br}-\mathrm{B}$ & $\begin{array}{l}\text { possibly specialized in } \\
\text { short vegetation }\end{array}$ & \multirow[t]{2}{*}{$\begin{array}{l}\text { regular browser living } \\
\text { in open woodland }\end{array}$} \\
\hline & $\begin{array}{l}\text { Romzolherimm } \\
\text { filholt }\end{array}$ & - & $\begin{array}{l}\text { *small to } \\
\text { medium-small }\end{array}$ & - & medium-small & cursorial & $\mathrm{Br}-\mathrm{B}$ & $\begin{array}{l}\text { possibly specialized in } \\
\text { short vegetation }\end{array}$ & \\
\hline
\end{tabular}

from Saulcet (NMB-Sau1662; Fig. 4a), Wischberg (NMB-AS75; SCHAUB \& HÜRZELER 1948) and Pyrimont-Challonge (UCBL-212997; DePÉRET \& DOUXAMI 1902). In fact, as suggested by CERDEÑO (1995), the development of nasal horns evolved independently to apomorphic states and with sometimes reversals to the plesiomorphic state (absence). Thus, the occurrence of paired nasal horns in D. asphaltense is rather interpreted as a convergence with that in Diceratherium, Menoceras and Pleuroceros. However, DE Bonis (1973) excludes the existence of a double nasal horn for $D$. asphaltense from Pyrimont-Challonge, because the lateral rough bumps are too weak. He notes also that the young forms of extant rhino- ceroses with a unique nasal horn show commonly symmetric rough bumps on the nasal tip getting larger and fused with years. Additionally, the development, the presence and the absence of horns can often be linked to sexual dimorphism (AnTOINE 2002, Prothero 2005). For all these reasons, the "horn" in the Rhinocerotidae is not a "good" diagnostic character (ANTOINE, pers. comm.). In this way, we cannot exclude that the lack of horn in the Eschenbach specimen is a consequence of the juvenile state, the sexual dimorphism or a reversal to the plesiomorphic state, even so no horned skull of D. lemanense is mentioned in the literature, except LAVOCAT (1951) who considers $D$. lemanense and $D$. aginense as syno- 
nyms. Nevertheless, numerous authors report the presence of nasal horn in Diaceratherium species in addition to the $D$. asphaltense ( $D$. aurelianense from Artenay, Neuville-aux-Bois, Chilleurs-auxBois, Nouel 1866 and CERdeño 1993; D. aginense from Laugnac, RÉPELIN 1917 and DE BonIS 1973; D. tomerdingense from Tomerdingen, DIETRICH 1931).

The main characters of the Eschenbach skull (long and fine nasals, deep U-shaped nasal notch reaching the middle of the $\mathrm{P} 3$, postglenoid and posttympanic apophyses in contact, slight posterior elevation and enlargement of the zygomatic arch, weakly separated sagital crests, slight dome on the nasal posterior edge, occipital side inclined backward) are very close to those of the Diaceratherium lemanense from Gannat, illustrated by ROMAN (1911: Pl. VIII, fig. 1 and 1a). However, the Eschenbach skull exhibits a slight flexure of the zygomatic arch in its posterior half, indicating probably a more evolved state. This character is associated with a lateral enlargement in $D$. asphaltense and $D$. aurelianense, while the zygomatic arch of $D$. aginense is rectilinear while elevated and broad.

The skull from Engehalde (NMBE-D3193; Fig. 4b) ascribed to Acerotherium gannatense by OOSTER \& von Fischer-Ooster (1871; P1. 1 and 2) is fairly different, displaying an elevated and strongly curved zygomatic arch, a high and robust nasal, and a high skull in lateral view. But these characters seem to be artefacts due to a transverse flatness of the skull which have elevated the arches, narrowed the orbitotemporal opening and curved the nasals. Moreover, it is impossible to observe the occlusal view of the back teeth on this skull. For all these reasons, we ascribe this material to Diaceratherium cf. lemanense.

The dental structures of the Eschenbach skull exhibit some evolved features (crista and crochet developed and fused on premolars, very marked posterior wing shape of ectoloph in the M1 and M2, stronglydeveloped crochet on molars, triangular M3), which are present in $D$. aginense (e.g. D. aginense from Laugnac, RÉPELIN 1917; D. aginense from Béthusy, MGL-3356, Fig. 4 e; ENGESSER et al. 1993) and in the evolved D. lemanense from Saint-Gérand-le-Puy (BRUNET et al. 1987). However, the dental biometrical data of $D$. aginense are systematically larger, quite as those of the specimen from Saint-Gérand-le-Puy (Tab. 8). Of course, the Eschenbach skull belongs to a juvenile specimen and could be a female as well.
In comparison, the toothrow of $D$. lemanense from Cindré, illustrated by RoMAn (1911; P1. VIII, fig. 2a), seems more primitive, exhibiting a slightly subquadratic M3, a posterior wing-shaped ectoloph less marked on M1 and M2, and a crochet poorly developed in the molars. The back tooth structure of $D$. asphaltense is also quite different with mainly molariform premolars, a subquadratic M3, a weakly developed or absent crochet on the molars, and a less-marked posterior wing-shaped ectoloph on M1 and M2 (e.g. D. asphaltense from Saulcet, NMB-Sau1662, Fig. $4 \mathrm{~d}$; D. asphaltense from Pyrimont-Challonges, UCBL-212997, Depéret \& DouXAmi 1902). Concerning the enigmatic D. tomerdingense of DIETRICH (1931), the differences are obvious: larger size (Tab. $8)$, no parallelism between the protoloph and the metaloph of the P3, no antecrochet on molars. Moreover, the metapods of $D$. tomerdingense are indisputably stouter in comparison with those of D. lemanense from Gannat exhibited in the NMB (pers. obs.). As noted by Michel (1983) in order to distinct D. lamilloquense from $D$. lemanense, the former differs from the Eschenbach specimen by a larger L/W ratio of the back teeth and more primitive dental characters (less advanced molarisation of the premolars and less developed antecrochet on molars). As there is no comparison material of $D$. cf. lemanense from Thézels, we consider, following MicHEL (1983) and BRUNET et al. (1987), that the latter is more evolved than $D$. lamilloquense and more primitive than $D$. lemanense. Finally, the dental series of the Eschenbach specimen are too primitive to belong to $D$. aurelianense, which presents molariform premolars, very strong paracone folding and well-developed crochet, crista and antecrochet on molars (GINSBURG et al. 1981, CERDEÑO 1993).

The set of morphological features on the Eschenbach skull and the comparison with other European specimens ascribe it to Diaceratherim lemanense (POMEL 1853). It is probably in a more evolved state than the Gannat specimen and although its dental structures are closer to those of the SaintGérand-le-Puy specimen, it shows certainly a more primitive state than the latter.

\subsection{Ontogeny}

The age of the Eschenbach specimen can be estimated from the dental formula of the back teeth - D1-P2P3-D4-M1-M2 - and the computed tomography data. The latter allowed the description of the un- 
erupted teeth $\mathrm{P} 4$ sin. and M3 sin., and also the growing state of the adult tooth eruption. According to GUÉRIN (1980), the eruptions of the P4 and the M3 are the two last steps prior to the adult state. The absence of an unerupted P1, as shown by the computed tomography, indicates a persistent D1. As discussed by Prothero et al. (1986) and Prothero (2005), the first deciduous premolars D1/d1 of most perissodactyls are never replaced but retained until adulthood or lost without a replacement tooth. This is even the prevailing condition in the Rhinocerotidae (ButLer 1952). Consequently, the juvenile state of the specimen is not underlined by the retention of the D1, but above all by the non-eruption of the P4 and the M3. According to NowaK (1999), the adult state of the closer living rhinoceros (Diceros bicornis) of D. lemanense is reached between 7 and 10 years. Assuming the same case in the fossil rhinocerotids, the Eschenbach specimen is probably between 5 and 7 years old.

\subsection{Biostratigraphy (Fig. 8)}

The first European occurrence of diaceratheres is the D. lamilloquense from La Milloque (France), in the Mammal Zone MP29 (BRUNET et al. 1987), just at the beginning of the "Terminal Oligocene Crisis". During MN1 (earliest Miocene), this rhinocerotid group shows a relatively high diversity with three species (D. lemanense, D. asphaltense and D. tomerdingense), spreading from south-western France to eastern Switzerland and southern Germany. During MN2a, the Diaceratherium lineage is still represented by $D$. lemanense, but also by the first representatives of $D$. aginense. Diaceratherium cf. aurelianense appears during MN2b in Spain and is contemporaneous with the last $D$. lemanense and $D$. aginense. From MN3, only $D$. aurelianense persists, mainly in France, but also in the Iberian Peninsula, in Switzerland and in Germany. During MN4a, just after the "Proboscidean Datum Event", the last occurrence of $D$. aurelianense is recorded in Artenay, France (GINSBURG 1989a, 1989b, CERDEÑO 1993), whereas the first occurrence of Brachypotherium is recorded in Artesilla (Spain) with B. cf. brachypus (AzANZA et al. 1993, CERDEÑO 1993). SACH \& HEIZMANN (2001) note the occurrence of a D. cf. aurelianense in Germany (MN4b, Eggingen-Mittelhart 3).

Diaceratherium lemanense is widespread in the early Miocene of Germany, Switzerland and France, and appears to be the dominating species during MN1
(BRunet et al. 1987, Duranthon 1991, Antoine et al. 2006). According to the complete biostratigraphical record, this species is probably not restricted to the MN1 biozone, but ranges from MP30 with the primitive $D$. aff. lemanense from Thézels (COMTE 2000) and D. lemanense from Rott bei Bonn (vON Koenigswald et al. 1992, Mörs 2002) to MN2 with more evolved forms (Saint-Gérand-le-Puy and Montaigu-le-Blin, France, Hugueney 1997; Budenheim, Germany, Roman 1924). Consequently, the more evolved D. lemanense reported from Eschenbach is a new biostratigraphical pinpoint within the Granitischer Sandstein Formation. The taxonomical affinities assign it to the MN2a biozone. Diaceratherium lemanense Eschenbach is probably slightly younger than that from Cindré and slightly older than that from Saint-Gérand-le-Puy, but certainly older than $D$. aginense from Béthusy. In addition, the presence of $D$. cf. lemanense in Engehalde does not allow a more precise dating of this locality than the MN1-2 interval.

\subsection{The Oligo-Miocene transition}

Generally, the Diaceratherium lineage is characterised by mesodont back teeth, deep molar median valleys and fossettes, a deep nasal notch, mediportal to graviportal limbs and the retention of a fifth functional manus digit (DE Bonis 1973, Michel 1983, BRUNET et al. 1987). Within the large mammal herbivores, these features are interpreted as an aptitude to a slightly abrasive plant intake (FoRTELIUS et al. 2002, 2003), as a presence of a useful prehensile lip to a feeding intake (GUÉRIN 1980, UHLIG 1999) - but normally coupled with retracted nasals after PROTHERO (2005) - and as a development of a certain amphibious way of life (CERDEÑO 1998, HEISSIG 1999). After Cerdeño \& Nieto (1995) and Cerdeño (1998), the diaceratheres are associated to swampy habitats within woodland environments, where they live in relatively large groups like extant hippopotamuses. Their diet is composed of leaves and swampy short vegetation. However, these interpretations consider mainly the last species of the lineage (D. aurelianense). In fact, the diaceratheres are not necessarily associated to wetlands. For example, D. tomerdingense was found within a fissure filling located in the dry hinterland of lake environments from the USM in Baden-Württemberg (HeIZMANN, pers. comm.). Moreover, MiHLBACHLER (2005) argues that the shortened limbs of extinct hippo-like ungulates (in- 


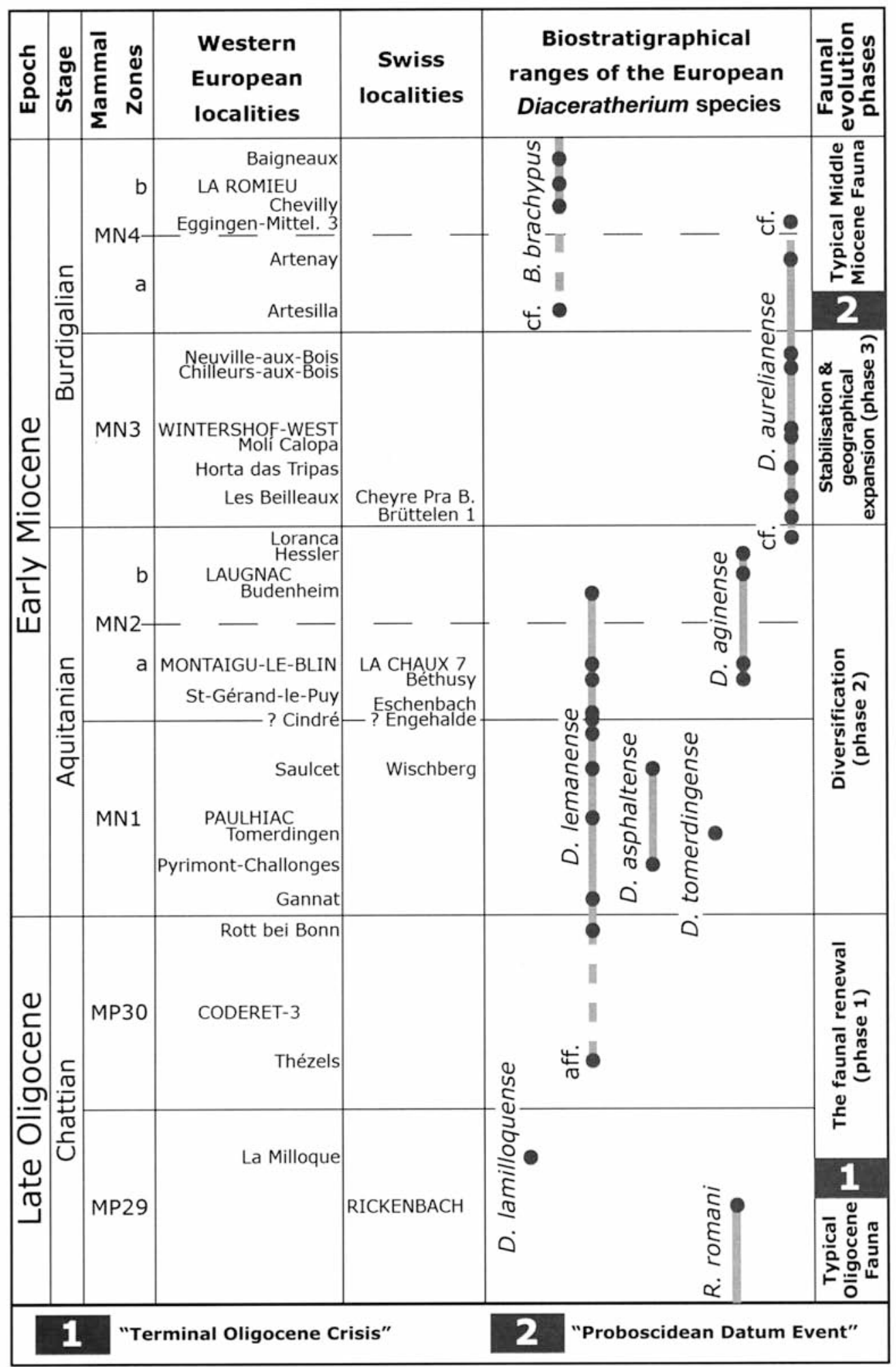

Fig. 8. Biostratigraphical ranges of the European Diaceratherium species compared with the LAD of Ronzotherium romani and the FAD of Brachypotherium brachypus in Western Europe (based on references in Table 3; SCHMIDT-KITTLER 1987, MeIn 1989, 1999, ENGESSER \& MödDEN 1997, HeIssig 1999). 
cluding teleoceratines) are not clearly indicative of an aquatic lifestyle. An alternative hypothesis that the shortened limbs may have had more to do with open terrain and grazing habits is also possible. However, only few diaceratheres (D. tomerdingense, evolved $D$. lemanense, $D$. aginense) could be mixed feeders (browsers-grazers) in quite closed habitats (bushland, woodland or forest), but can never be true grazers.

The Diaceratherium genus is assumed to be a good representative of the Oligo-Miocene transition, from the "Terminal Oligocene Crisis" to the "Proboscidean Datum Event" (see Tab. 8: MP29-MN4 locality coverage, $\% D .>30 \%$ ). This time interval (MP29MN4) is controlled by climatic and environmental changes and interaction phenomena (e.g. competition). The locality distribution patterns and the palaeoecological character evolution (e.g. body mass, feeding behaviour) of the Diaceratherium species seem to be a good proxy for understanding population fluctuations and pointing out climatic and environmental changes (especially during the MN1-3 interval). As it is illustrated in Figures 7 and 8 , the Oligo-Miocene transition can be subdivided in three phases preceded by a "Typical Oligocene Fauna" and followed by a "Typical Middle Miocene Fauna".

\subsection{The typical Oligocene fauna}

Late Oligocene (until Rickenbach level). A detailed environmental and climatic evolution of the Oligocene is beyond the scope of this study. Despite the cooling event in the mid-Oligocene (HAQ et al. 1987, ProTHERO 1994), the trend of an opening and a slight aridification of the environments in MP28 (COSTEUR 2005) and some significant faunal changes (see Introduction), we state that during the main part of the Oligocene the European climate was quite stable, generally marked by temperate conditions and several times partially associated with a vegetation of swamps and mangroves, as shown by REICHENBACHER et al. (2004) for the early Oligocene of the southern German Molasse. The late Oligocene records the FAD of Diaceratherium in Thailand with $D$. cf. lamilloquense (see MARIVAuX et al. 2004). This occurence suggests an Asian origin for the European diaceratheres, as previously assumed by CERDEÑO (1998). The Rickenbach locality in Switzerland (European Reference Level for MP29) records the LAD of Ronzotherium romani. This species is a typical Oligocene cursorial regular browser, feeding on quite short vegetation and inhabiting in dry open woodland. It has a relatively important size and weight compared to other contemporaneous mammals, but its weight is less important than in early Miocene diaceratheres. It disappears at the same time than Anthracotherium and Micobunodon, prior to the "Terminal Oligocene Crisis". The common Ronzotherium-Anthracotherium association in the Oligocene European localities (e.g. Kleinblauen, Villebramar, La Ferté-Alais, Bumbach, Rickenbach) is typical for dry open woodlands associated with marshy forests (UHLIG 1999). EMERY et al. (2007) support an open and dry environment maybe a scrub woodland type - for the Rickenbach mammal community. After TÜTKEN (pers. comm.), the enamel isotope composition from teeth of Rickenbach large mammals underlines a temperature peak probably analogous to the "Late Oligocene Warming" (cf. ZACHOs et al. 2001).

\subsection{Faunal renewal (phase 1)}

MP29 (from La Milloque level). This time interval coincides with the FAD of Diaceratherium in Europe - D. lamilloquense from La Milloque (France; BRUNET et al. 1987) - at the beginning of the "Terminal Oligocene Crisis". This crisis is well documented in Switzerland by floral variations and important climatic changes, prior to the Oligocene/Miocene boundary (BERGER 1989, 1990a, 1990b): the presence of palms and taxads during the Oligocene shows a warm and humid climate, while their disappearance at the end of the Oligocene (at MP29) suggests a critical decrease of temperature and humidity. According to Costeur (2005), it seems to have some local and/or regional differences (e.g. the German localities of this biozone display more humid conditions). Diaceratherium lamilloquense exhibits a weak crown height and an early tendency to the brachypody, but does not yet reach the weight and the size of the Miocene diaceratheres (e.g. D. aginense, $D$. aurelianense). The drastic climatic and environmental changes, which generated drier and colder conditions, have probably forced this rather regular browser to inhabit refuge areas such as dense forests close to water sources. This is in agreement with the open and dry environments deduced by Costeur (2005) for the MP29-30 interval. Additionally - and contrary to ronzotheres which only have a reduced McV (BRUNET 1979) -, the diacerathere group is defined by the holding back of a fifth functional manus digit (Michel 1983, Brunet et al. 1987). This feature 
could be interpreted as an aptitude for living in swampy habitats or at least in humid wooded habitats with a moist and soft ground (DE BoNIS 1973, HeIssig 1999).

MP 30. The diacerathere record of this biozone is restricted to $D$. aff. lemanense from Thézels (BRUNET et al. 1987) and D. lemanense from Rott bei Bonn (von Koenigswald et al. 1992, Mörs 2002). The specimen from Thézels could represent the FAD of a primitive form of $D$. lemanense, probably derived from $D$. lamilloquense, from which it shows a closer anatomical type but with a slight increase of the crown height and body mass. It seems to be a regular browser inhabiting a different ecological niche, maybe in the transitional zone between forest and grassland, with available water. This could be related to the temporal vanishing of the forested refuge areas, associated with the opening of woodland habitats and an increasing seasonality.

\subsection{Diversification (phase 2)}

MN1. The diaceratheres are characterized by an increase of their diversity (D. lemanense, D. asphaltense, D. tomerdingense) and a first geographical spreading, from south-western France to eastern Switzerland and southern Germany. Some localities such as Saulcet (France) and Wischberg (Switzerland) could maybe also record two sympatric species $(D$. lemanense and $D$. asphaltense). The first representatives of a rather intermediate head holding are present with $D$. asphaltense, a probably rather high browser. The species of this time interval show an increase of the hypsodonty index, in particular $D$. tomerdingense $(\mathrm{I}-\mathrm{Hy}=120.00)$. However, the latter is only known in Tomerdingen in Germany and could represent a local speciation. Several anatomical types are represented mediportal to graviportal types, medium-small to medium-large body masses and sizes -, characterising forms adapted to mosaic environments ranging from the dense or slightly open forests to the bushland. These observations are in agreement with those of Berger (1989, 1990a, 1990b) and Costeur (2005) respectively based on floral changes and mammal community analyses. The general conditions remain open and dry, and the climate seems to support the bush and thorn-bush expansion. In western Switzerland the reappearance of palms - combined with the absence of Taxodiaceae and the diversification of Leguminosae - indicates an increase of the temperature coupled with low humidity. Furthermore,
Costeur (2005) assumes that environments are becoming scattered in mosaic form.

MN2. The FAD of the evolved D. lemanense (e.g. in Eschenbach; Fig. 9) and the possible speciation of D. aginense within MN2a of Switzerland (e.g. in Béthusy) highlight the second part of the diacerathere diversification. In fact, this earliest local occurrence of D. aginense in Switzerland (in the lower Aquitanian Molasse grise localities; ENGESSER et al. 1993) could be related to a local meandering river system. Diaceratherium aginense is a large, mediportal, and rather high browser with an intermediate head holding probably depending on wet ecological niches like swamps or water beds. It is currently difficult to state whether it derives from an evolved form of D. lemanense or from $D$. asphaltense, since it presumably shares advanced common characters of these two species. This biozone and maybe also the MN3 biozone coincide with the only supposed Miocene spreading of the diaceratheres outside Europe, according to the occurrence of $D$. askazansorense in southern Kazakhstan (KoRDIKOvA 2001).

The end of the MN2 biozone underlines the end of the diacerathere diversification phase, whilst the increasingly warmer climate becomes wetter again. The diacerathere group is dominated by $D$. aginense and the last evolved $D$. lemanense spreading in France (Aquitaine and Paris basins) and in Germany (Rheinhessen basin). Diaceratherium localities are not any more recorded in Switzerland and in south-eastern France, probably because of a palaeogeographical configuration controlled by the transgression of the perialpine Burdigalian Sea from south-western France to the Swiss Molasse Basin (OMM = Obere Meeresmolasse $=$ Upper Marine Molasse, MN2b-MN4). In the Iberian Peninsula, the FAD of $D$. cf. aurelianense is recorded in Loranca (MN2b). According to BRUNET et al. (1987), this new species probably derives from D. aginense and its occurence in Spain could be linked to the geographical expansion of the latter.

The diacerathere diversity of this time interval still seems to be controlled by environments scattered in mosaic form, composed by dense to slightly open forests (D. aginense, D. aurelianense) and bushland to woodland (evolved D. lemanense). However, an onset to rather more closed and more humid conditions seems to be supported by the increasing gracility index of the evolved D. lemanense (e.g. D. lemanense from Budenheim, Roman 1924). This change of environmental pattern strenghtens the hypothesis of a display of latest Aquitanian subtropical woodland type 


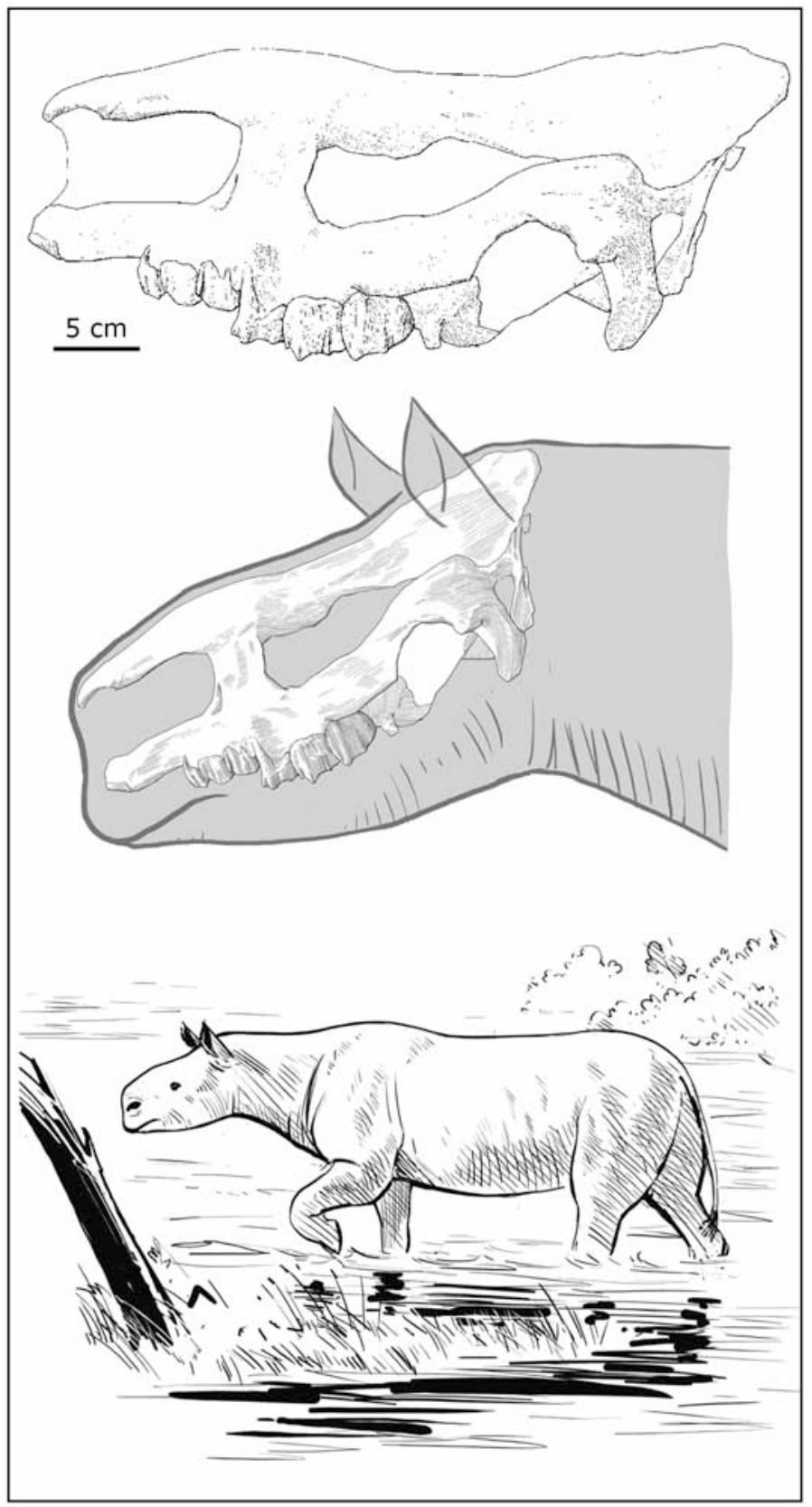

Fig. 9. Reconstitution of the Diaceratherium lemanense from Eschenbach (Aquitanian, eastern Switzerland). Drawing by Tayfun Yilmaz (Office de la culture, Canton Jura, Switzerland).

environments suggested by BECKER et al. (2001) in the Swiss Molasse Basin.

\subsection{Stabilisation and geographical expansion (phase 3)}

MN3. This biozone coincides with the beginning of the "Miocene Climatic Optimum" (BöHME 2003). During this time interval the European diacerathere species are restricted to D. aurelianense. However, they underline the greatest spreading of the group from the Iberian Peninsula to Germany and Switzerland. The occurences in the two latter areas are restricted to the northern littoral environments of the Burdigalian Sea. Diaceratherium aurelianense is slightly smaller and more graviportal than $D$. aginense. It is probably a true high browser, having a head holding intermediate to up, and is adapted to forest environments close to water beds or swamps of closed woodland to rain forest types. These environ- 
ments are in conformity with the closed and wet conditions suggested by CosTEUR (2005).

\subsection{The typical Middle Miocene fauna}

MN4. During this time interval the collision of Africa and Arabia with Eurasia closes the seaway between the Mediterranean Sea and the Indian Ocean (RöGL 1999). A new land bridge enables a distinct mammal migration between the two continents (Gomphotherium land bridge of the "Proboscidean Datum Event"), resulting of an ecological bottleneck for the mammal community, because of many migration waves (e.g. African gomphotheres, Asian brachypotheres) and a stronger continental climatic control on the circumMediterranean lands. After BECKER (2003), northern Switzerland shows an increasing seasonality. The environments become dryer again and the humid forested areas are no longer dominating. At MN4a, the last localities of $D$. aurelianense are still recorded in Spain and in France in the north-western part of the perialpine Burdigalian Sea. The LAD of diaceratheres is recorded in the eastern part of the German Molasse Basin (D. cf. aurelianense from Eggingen-Mittelhart 3 ; MN4b) where the regression of the OMM is ended, whereas the FAD of brachypotheres is recorded in Europe with $B$. cf. brachypus from Artesilla in Spain (MN4a). After CERdeño (1998), the latter migrates from Asia. It probably occupies a quite different ecological niche of that of $D$. aurelianense. With its larger body size and mass, its more advanced brachypody and its lower head holding, it seems better adapted to shorter vegetation and could rather be a regular browser. After HeIssig (1972), the brachypotheres seem well adapted to intermediary climatic conditions and not sensitive to weak changes. Even if less common, they are still present in extreme conditions (humid or dry). Thus, it could be assumed that the environments show a slight decrease of the forested area density and humidity. This fits well with the complete lost of their fifth manus digit - contrary to the diaceratheres.

At the end of this biozone, all the Diaceratherium representatives completely disappear, overtaken by the brachypotheres, which are at the beginning of their geographical expansion like other typical middle Miocene European taxa (e.g. Gomphotherium, Lagomeryx, Palaeomeryx, Plesiaceratherium, Prosantorhinus).

\section{Conclusions}

The study of the diacerathere skull from Eschenbach presented in this paper supports its attribution to Diaceratherium lemanense (PoMEL 1853). The description of morphological features, the comparison with other Diaceratherium species and the tomography analyses allow the following conclusions and comments: (1) Its back tooth pattern exhibits evolved features close to $D$. lemanense from Saint-Gérand-lePuy and D. aginense from Béthusy. For these reasons we suggest the distinction between a primitive form (e.g. Gannat, Paulhiac) and an evolved form (e.g. Eschenbach, Saint-Gérand-le-Puy) of D. lemanense. The locality of Eschenbach seems to be older than Saint-Gérand-le-Puy (MN2a) and slightly younger than Cindré (MN1-2), thus it can be allocated to the MN2a biozone. (2) The computed tomography data and the growing state of the adult tooth eruption, compared with the ontogeny of the closest living relative (Diceros bicornis), suggest that the skull of Eschenbach belongs to a 5 to 7 years old specimen.

The regional level analysis of European diacerathere species distribution and palaeoecology illustrates the evolutionary trends that allowed the subdivision of the Oligo-Miocene transition biogeographical context into three successive phases, plotted between two events:

(1) The faunal renewal: After the disappearance of the ronzothere group in the beginning of the "Terminal Oligocene Crisis", the Diaceratherium genus takes place in Europe (probably originating from D. cf. lamilloquense of Nong Ya Plong, Thailand). Currently, there is not any reasonable explanation clarifying the European latest Oligocene extinction of the Ronzotherium genus (and other taxa such as Anthracotherium). A real competition between the last Ronzotherium and the first Diaceratherium does not seem to exist. No synchronous localities are known and the arrival of diaceratheres in Europe seems really timorous (MP29, FAD with D. lamilloquense from La Milloque; MP30, D. aff. lemanense from Thézels and D. lemanense from Rott bei Bonn). Moreover, it is difficult to estimate the existence of a record bias because of the rather low abundance of large mammal localities during the MP29-30 interval. These primitive forms of diaceratheres are regular browsers probably occupying slightly different ecological niches, in increasingly open environements.

(2) The diversification phase: During the Aquitanian, the diaceratheres present a great diversity sup- 
ported by the FAD of $D$. aginense (MN2a) and $D$. aurelianense (MN2b), the LAD of D. lemanense (MN2b) and $D$. aginense (MN2b), the restricted $D$. asphaltense to the MN1 biozone and the local occurrence of $D$. tomerdingense (MN1). This diversity supports a mix of regular and high browsers inhabiting different ecological niches in an environment scattered in mosaic form (bushland to forested areas). The speciation of $D$. aginense seems to take place in the Swiss Molasse Basin (upper part of the Molasse grise de Lausanne Formation, MN2a; e.g. Béthusy), but its derivation species (D. lemanense or $D$. asphaltense) has still to be clarified. Nevertheless, it is assumed that $D$. aurelianense derives from $D$. aginense. Its first record in Loranca (Spain) also corresponds to the first diacerathere occurrence in the Iberian Peninsula. This data could suggest a late (MN2b) expansion of the diaceratheres from the Pyrenees to Spain, and also the speciation of $D$. aurelianense since there. Also, we assume the spreading outside Europe of D. askazansorense in the early Miocene of southern Kazakhstan.

(3) The stabilisation \& geographical expansion phase: Diaceratherium askazansorense could still to be present in southern Kazakhstan, but during the Burdigalian, the European diaceratheres are exclusively represented by $D$. aurelianense. This high browser graviportal rhinoceros seems to be well adapted to forested environments close to water beds or swamps. It supports the greater geographical expansion of the group associated with the likely generalisation of Western European humid forested environments. This environmental type is no longer dominating due to the beginning of the "Miocene Climatic Optimum" which leads to aridification associated to an increasing seasonality. During the "Proboscidean Datum Event" the competition for the same ecological niche - implied by the arrival of the first European Brachypotherium migrated from Asia-, leads to the extinction of the diaceratheres. The first record of Brachypotherium cf. brachypus in MN4a at Artesilla (Spain) and the extension of $D$. cf. aurelianense up to MN4b at Eggingen-Mittelhart (Germany) could suggest that the first brachypotheres arrived in Europe via the Alpine Arch pathway as defined by ANTUNES (1989), but the normal European pathway cannot be excluded.

The observed evolutionary trends tend to support the appropriate time resolution of this study (biochronological units ranging in a time-scale of $10^{5}-10^{6}$ years) for long-term change descriptions over several millions years in a phyletic lineage, although the observed morphological changes seem to be assumed at a $10^{5}$ years time-scale. The observed environmental variations during the Western European Oligo-Miocene transition, supported by these results, are moderate and progressive, and also associated to a diacerathere reaction mainly consisting of local extinctions, colonisation events and phyletic evolutions. On another hand, drastic palaeogeographical changes coupled with drastic environmental changes and migrations, as observed from the "Proboscidean Datum Event" and the "Miocene Climatic Optimum", would imply a more severe faunal response coupled with faster extinction than renewal.

\section{Acknowledgements}

This project was financially supported by the Swiss National Science Foundation (project 200021-115995) and the Office de la Culture (Canton Jura, Switzerland). We thank Ursula Menkveld-Gfeller, Bernhard Hostettler and Peter Vollenweider (Naturhistorisches Museum Bern), Burkhart Engesser and Arne Ziems (Naturhistorisches Museum Basel), Robin Marchant (Musée cantonal de géologie de Lausanne), and Claude Guérin and Abel Prieur (University of Lyon I) for providing access to the diacerathere fossils from the museum and institution collections. We also thank Alexander Flisch (EMPA Dübendorf) for the computed tomography and Ralph Schindel (Institute for Rapid Product Development, FHS St. Gallen) for the 3D reconstructions. Heinz Furrer (Paläontologisches Institut und Museum der Universität Zürich) and Hans Jakob Siber (Sauriermuseum Aathal) are gratefully acknowledged for their support and their helpful information, as well as Pierre-Olivier Antoine, Jean-Pierre Berger, JeanPaul Billon-Bruyat, Loïc Bocat, Loïc Costeur, Bastien Mennecart and Thomas Tütken for very valuable discussions. Sincere thanks are due to Donald Prothero for comments about a first version of this paper and to the reviewers, Kurt Heissig and Elmar Heizmann. Special thanks go to Reto Zwicky, the discoverer of the diacerathere skull from Eschenbach, Tayfun Yilmaz for drawing the reconstitution of the Eschenbach specimen, Bernard Migy for taking the photographs, and Elias Samankassou and Daniel Marty who kindly improved the English.

\section{References}

Aguilar, J.-P., Antoine, P.-O., Crochet, J.-Y., LóPezMartínez, N., Métais, G., Michaux, J. \& Welcomme, J.-L. (2003): Les mammifères du Miocène inférieur de Beaulieu (Bouches-du-Rhône, France), comparaison avec Wintershof-West et le problème de la limite MN3/MN4. - Coloquios de Paleontologia Volume Externe, 1: 1-24. 
Antoine, P.-O. (2002): Phylogénie et évolution des Elasmotheriina (Mammalia, Rhinocerotidae). - Mémoire du Muséum National d'Histoire Naturelle de Paris, 188: $1-359$.

Antoine, P.-O., Bulot, C. \& Ginsburg, L. (2000): Les rhinocérotidés (Mammalia, Perissodactyla) de l'Orléanien des bassins de la Garonne et de la Loire (France): intérêt biostratigraphique. - Comptes Rendus de l'Académie des Sciences de Paris, 330: 571-576.

Antoine, P.-O., Duranthon, F., Hervet, S. \& Fleury, G. (2006): Vertébrés de l'Oligocène terminal (MP 30) et du Miocène basal (MN1) du métro de Toulouse (sud-ouest de la France). - Comptes Rendus Palevol, 5: 875884.

Antunes, M. T. (1989): The Proboscideans Data, Age and Palaeogeography: Evidence from the Miocene of Lisbon. - In: Lindsay, E. H., Fahlbusch, V. \& Mein, P. (Eds.): European Neogene Mammal Chronology. NATO Advanced Science Institutes Series, Life Scences, New York, London (Plenum Press), 180: 253-262.

Azanza, B., Cerdeño, E., Ginsburg, L., Van Der Made, J., Morales, J. \& Tassy, P. (1993): Les grands mammifères du Miocène inférieur d'Artesilla, bassin de Calatayud-Teruel (Province de Saragosse, Espagne). Bulletin du Muséum National d'Histoire Naturelle de Paris, 15: 105-153.

BALES, G. S. (1996): Skull evolution in the Rhinocerotidae (Mammalia, Perissodactyla): cartesian transformations and functional interpretations. - Journal of Mammalian Evolution, 3: 261-279.

BECKER, D. (2003): Paléoécologie et paléoclimats de la Molasse du Jura (Oligo-Miocène): apport des Rhinocerotoidea (Mammalia) et des minéraux argileux. - PhD Thesis, University of Fribourg, GeoFocus, 9: 327 pp.

BECKER, D. (2004): Rhinocerotoidea and clay minerals of the Jura Molasse (Oligo-Miocene, Switzerland): implications for paleoecology and paleoclimates. - Journal of Vertebrate Paleontology, 24: p. 37A.

Becker, D., Rössner, G., Picot, L. \& Berger, J.-P. (2001): Early Miocene ruminants from Wallenried (USM, Aquitanian/Switzerland): biostratigraphy and paleoecology. Eclogae geologicae Helvetiae, 94: 547-564.

Berger, J.-P. (1989): Paläoökologie und Paläoklimatologie einiger oligozänen Floren der westschweizerischen subalpinen Molasse. - Courier Forschungs-Institut Senkkenberg, 109: 207-228.

- (1990a): Le rôle des environnements de dépôt pour les reconstitutions climatiques: les gisements à végétaux de la Molasse grise de Lausanne (Miocène inférieur, Suisse occidentale). - Paléobiologie Continentale, Montpellier, 17: 345-353.

(1990b): Floral changes in the Molasse of Western Switzerland (Oligo-Miocene): paleoclimatic implications. - In: KNOBLoch, E. \& KvaceK, Z. (Eds.): Symposium paleofloristic and paleoclimatic changes in the Cretaceous and Tertiary, Prague Proceeding Volume, 189-194. Geological Survey Publisher, Prague.

- (1998): "Rochette" (Upper Oligocene, Swiss Molasse): a strange example of a fossil assemblage. - Review of Palaeobotany and Palynology, 101: 95-110.
Berger, J.-P., Reichenbacher, B., Becker, D., Grimm, M., Grimm, K., Picot, L., Storni, A., Pirkenseer, C., Derer, C. \& Schaefer, A. (2005): Paleogeography of the Upper Rhine Graben (URG) and the Swiss Molasse Basin (SMB) from Eocene to Pliocene. - International Journal of Earth Sciences, 94: 697-710.

BlaINVILle DE, H. M. D. (1839-1864): Ostéographie des mammifères et atlas. - 232 pp., Paris (J. B. BAILlÈRE \& FILS).

Blondel, C. (1997): Les ruminants de Pech Desse et de Pech du Fraysse (Quercy; MP28); évolution des ruminants de l'Oligocène d'Europe. - Geobios, 30: 573-591.

BöHme, M. (2003): Miocene Climatic Optimum: evidence from Lower Vertebrates of Central Europe. - Palaeogeography, Palaeoclimatology, Palaeoecology, 195: 389-401.

BoNIS, L. DE (1973): Contribution à l'étude des mammifères de l'Aquitanien de l'Agenais: rongeurs, carnivores, périssodactyles. - Mémoires du Muséum National d'Histoire Naturelle de Paris, 28: 192 pp.

BRunet, M. (1979): Les grands mammifères chefs de file de l'immigration oligocène et le problème de la limite Eocène-Oligocène en Europe. - 281 pp., Paris (Fondation Singer-Polignac).

Brunet, M., DE Bonis, L. \& Michel, P. (1987): Les grands Rhinocerotidae de l'Oligocène supérieur et du Miocène inférieur d'Europe occidentale: intérêt biostratigraphique. - Münchner Geowissenschaftliche Abhandlungen, 10: 59-66.

Butler, P. M. (1952): The milk-molars of Perissodactyla, with remarks on molar occlusion. - Proceedings of the Zoological Society of London, 121: 777-817.

Cerdeño, E. (1992): Spanish Neogene Rhinoceroses. Palaeontology, 35: 297-308.

CERdeño, E. (1993): Etude sur Diaceratherium aurelianense et Brachypotherium brachypus (Rhinocerotidae, Mammalia) du Miocène moyen de France. - Bulletin du Muséum National d'Histoire Naturelle de Paris, 15: 25-77.

Cerdeño, E. (1995): Cladistic analysis of the Family Rhinocerotidae (Perissodactyla). - American Museum Novitates, 3143: 25 pp.

- (1998): Diversity and evolutionary trends of the Family Rhinocerotidae (Perissodactyla). - Palaeogeography, Palaeoclimatology, Palaeoecology, 141: 13-34.

CERDEÑO, E. \& NiETO, M. (1995): Evolution of Rhinocerotidae in Western Europe. Influence of climatic changes. - Palaeogeography, Palaeoclimatology, Palaeoecology, 114: $325-338$.

ChRISTIANSEN, P. (2002): Locomotion in terrestrial mammals: the influence of body mass, limb lentgh and bone proportions on speed. - Zoological Journal of the Linnean Society, 136: 685-714.

CoMTE, B. (2000): Rythmes et modalités de l'évolution chez les rongeurs à la fin de l'Oligocène: leurs relations avec les changements de l'environnement. - Palaeovertebrata, 29: 84-360.

Costeur, L. (2005): Les communautés de mammifères d'Europe de l'Oligocène supérieur au Pliocène inférieur: paléobiogéographie et paléobiodiversité des ongulés, paléoenvironnements et paléoécologie évolutive. - 
Unpublished PhD Thesis, University of Lyon I, 90: $124 \mathrm{pp}$.

Cuvier, G. (1834): Recherche sur les ossements fossiles. 435 pp., Paris (E. d'Ocagne).

DaAms, R., Freudenthal, M. \& Weerd van de, A. (1977): Aragonian, a new stage for continental deposits of Miocene age. - Newsletters of Stratigraphy, 6: 42-55.

Depéret, C. \& Douxami, H. (1902): Les Vertébrés oligocènes de Pyrimont-Challonges (Savoie). - Mémoires Suisses de Paléontologie, 29: 1-92.

Dietrich, W. O. (1931): Neue Nashornreste aus Schwaben (Diaceratherium tomerdingensis n.g. n. sp.). - Zeitschrift für Säugetierkunde, 6: 203-220.

Duranthon, F. (1991): Biozonations des molasses oligomiocènes de la region toulousaine par l'étude des mammifères. Apports à la connaissance du Bassin d'Aquitaine (France). - Comptes Rendus de l'Académie des Sciences de Paris, 313: 965-970.

Duvernoy, G. L. (1853): Nouvelles études sur les rhinocéros fossiles. - Archives du Muséum d'Histoire Naturelle de Montpellier, 7: 41-70.

EMERY, E. (2004): Le gisement de Rickenbach (canton de Soleure, Oligocène): étude paléontologique des grands mammifères et état actuel du bio-géotope. - Unpublished Master Thesis, University of Fribourg, 129 pp.

Emery, E., Tütken, T., Becker, D., Flückiger, P. \& BERger, J.-P. (2007): Rickenbach unter den Tropen... vor 25 Millionen Jahren! Bestimmung des Paläoklimas und der Paläoökologie anhand der Untersuchungen an fossilen Nashhornzähnen aus der Sammlung des Naturmuseums Olten. - Mitteilungen der Naturforschenden Gesellschaft des Kantons Solothurn, 40: 51-64.

Engesser, B. (1990): Die Eomyidae (Rodentia, Mammalia) der Molasse der Schweiz und Savoyens. Systematik und Biostratigraphie. - Mémoires Suisses de Paléontologie, 112: 1-144.

Engesser, B. \& Mödden, C. (1997): A new version of the biozonation of the Lower Freshwater Molasse (Oligocene, Agenian) of Switzerland and Savoy on the basis of fossil mammals. - In: Aguilar, J.-P., Legendre, S. \& MichauX, J. (Eds.): Actes du Congrès BiochroM'97. Mémoires et Travaux de l'Ecole pratique des Hautes Etudes, Institut de Montpellier, 21: 581-590.

Engesser, B., Ginsburg, L., Weidmann, M. \& Bucher, H. (1993): Les faunes de Mammifères et l'âge de la Molasse grise de Lausanne (Aquitanien). Bulletin de Géologie de Lausanne, 321: 209-259.

ForTELIUS, M. (coordinator) (2003): Neogene of the Old World Database of Fossil Mammals (NOW). - University of Helsinki, http://www.helsinki.fi/science/ now/.

Fortelius, M., Eronen, J., Jernvall, J., Liu, L., Pushkina, D., Rinne, J., Tesakov, A., Vislobokova, I., ZhANG, Z. \& Zhou, L. (2002): Fossil mammals resolve regional patterns of Eurasian climate change over 20 million years. - Evolutionary Ecology Research, 4: 1005-1016.

Fortelius, M., Eronen, J., Liu, L., Pushkina, D., Tesakov, A., Vislobokova, I. \& Zhang, Z. (2003): Continentalscale hypsodonty patterns, climatic paleobiogeography and dispersal of Eurasian Neogene large mammal herbivores. - Deinsea, 10: 1-11.

Fortelius, M., Eronen, J., Liu, L., Pushkina, D., Tesakov, A., Vislobokova, I. \& ZhanG, Z. (2006): Late Miocene and Pliocene large mammals and climatic changes in Eurasia. - Palaeogeography, Palaeoclimatology, Palaeoecology, 238: 219-227.

FrEI, H. P. (1979): Stratigraphische Untersuchungen in der subalpinen Molasse der Nordost-Schweiz zwischen Wägitaler Aa und Urnäsch. - Mitteilungen des Geologischen Instituts der ETH und Universität Zürich (N.F.), 233: 217 pp.

Gentry, A. W., Rössner, G. E. \& Heizmann, E. P. J. (1999): Suborder Ruminantia. - In: Rösnner, G. E. \& Heissig, K. (Eds.): The Miocene Land Mammals of Europe, 225-258; München (Verlag Dr. Friedrich Pfeil).

GinsBURG, L. (1988): La faune des Mammifères des sables miocènes du synclinal d'Esvres (Val-de-Loire). Comptes Rendus de l'Académie des Sciences de Paris, 307: 319-322.

- (1989a): Les Mammifères des sables du Miocène inférieur des Beilleaux à Savigné-sur-Lathan (Indre-etLoire). - Bulletin du Muséum National d'Histoire Naturelle de Paris, 11: 101-121.

- (1989b): The faunas and stratigraphical subdivisions of the Orleanian in the Loire Basin (France). - In: LindSAY, E. H., Fahlbusch, V. \& Mein, P. (Eds.): European Neogene Mammal Chronology. - NATO Advanced Science Institutes Series, Life Scences, New York, London (Plenum Press), 180: 157-176.

- (2005): Les mammifères du Miocène inférieur de Beaulieu à Rognes (Bouches-Rhône, France). - Bulletin du Muséum d'Histoire Naturelle de Marseille, 6: 23-33.

Ginsburg, L. \& Antunes, M. T. (1979): Les Rhinocérotidés du Miocène inférieur et moyen de Lisbonne (Portugal). Succession stratigraphique et incidences paléogéographiques. - Comptes Rendus de l'Académie des Sciences de Paris, 288: 493-495.

Ginsburg, L. \& Bonneau, M. (1995): La succession des faunes de mammifères miocènes de Pontigné (Maineet-Loire, France). - Bulletin du Muséum d'Histoire Naturelle de Paris, 16: 313-328.

Ginsburg, L. \& Hugueney, M. (1980): La faune des mammifères du Miocène inférieur de Selles-sur-Cher (Loiret-Cher). - Bulletin du Museum National d'Histoire Naturelle de Paris, 2: 271-276.

Ginsburg, L., Huin, J. \& Locher, J.-P. (1981): Les Rhinocerotidae (Perissodactyla, Mammalia) du Miocène inférieur des Beilleaux à Savigné-sur-Lathan (Indreet-Loire). - Bulletin du Muséum National d'Histoire Naturelle de Paris, 3: 345-361.

Ginsburg, L., Bonneau, M., Bucher, H., Buge, E., Dineur, H., Janvier, P., Tassy, P. \& Venec-Peyre, M. T. (1982): Les faunes de mammifères des sables continentaux miocènes inférieurs du synclinal d'Esvres au Nord de la Loire. - Bulletin de la Société Géologique de France, 24: 403-406.

Ginsburg, L., Broin De, F., Crouzel, F., Duranthon, F., Escuillie, F., Juillard, F. \& Lassaube, S. (1991): Les vertébrés du Miocène inférieur de Barbotan-les-thermes (Gers). - Annales de Paléontologie, 77: 161-216. 
Ginsburg, L., Cheneval, J., Janvier, P., Pouit, D. \& Sen, S. (2000): Les vertébrés des sables continentaux d'âge orléanien inférieur (MN3) de Mauvières à Marcillysur-Maulne (Indre-et-Loire), La Brosse à Meigné-leVicomte (Maine-et-Loire) et Chitenay (Loire-et-Cher). Geodiversitas, 22: 597-631.

GöHlich, U. B. (1999): Order Proboscidea. - In: RÖsSNER, G. E. \& Heissig, K. (Eds.): The Miocene Land Mammals of Europe, 157-168; München (Verlag Dr. Friedrich Pfeil).

GuÉrIN, C. (1980): Les rhinocéros (Mammalia, Perissodactyla) du Miocène terminal au Pléistocène supérieur en Europe occidentale. Comparaison avec les espèces actuelles. - Documents des Laboratoires de Géologie de l'Université de Lyon, 79: 1-401.

Haвicht, J. K. A. (1945): Geologische Untersuchungen im südlichen st. gallisch-appenzellischen Molassegebiet. Beiträge zur Geologischen Karte der Schweiz (N.F.), 83: 29.

Haвicht, J. K. A. (1987): Lexique stratigraphique international. Europe, Suisse, Plateau Suisse (Molasse). Commission Géologique Suisse et Service Hydrologique et Géologique National, 1: 528 pp.

Haq, B. U., Hardenbol, J. \& Vail, P. R. (1987): The chronology of fluctuating sea level since the Triassic. Science, 235: 1156-1167.

HeIM, A. (1902): Geologisches Gutachten betr. Rickenbahn (1900-1902). - Zürich (Jean Frey Ed.).

Heissig, K. (1972): Paläontologische und geologische Untersuchungen im Tertiär von Pakistan: 5. Rhinocerotidae (Mamm.) aus den unteren und mittleren SiwalikSchichten. - Bayerische Akademie der Wissenschaften, Mathematisch-Naturwissenschaftliche Klasse Abhandlungen, Neue Folge, Heft, 152: 112 pp.

Heissig, K. (1999): Family Rhinocerotidae. - In: Rössner, G. E. \& Heissig, K. (Eds.): The Miocene Land Mammals of Europe, 175-188; München (Verlag Dr. Friedrich Pfeil).

Hooker, J. J. (2000): Paleogene mammals: crises and ecological change. - In: Cluver, S. J. \& Rawson, P. F. (Eds.): Biotic Response to Global Change, 333-349; Cambridge (Cambridge University Press).

Hugueney, M. (1997): Biochronologie mammalienne dans le Paléogène et le Miocène inférieur du centre de la France: synthèse réactualisée. - In: AGUILAR, J.-P., Legendre, S. \& Michaux, J. (Eds.): Actes du Congrès BiochroM'97. - Mémoires et Travaux de l'Ecole Pratique des Hautes Etudes, Institut de Montpellier, 21: 417-430.

Hugueney, M., Poidevin, J.-L., Bodergat, A.-M., Caron, J.-B. \& GuÉRIN, C. (1999): Des mammifères de l'Aquitanien inférieur à La Roche-Blanche-Gergovie (Puy-deDôme, France), révélateurs de l'activité post-oligocène du rift en Limagne de Clermont. - Comptes Rendus de l'Académie des Sciences de Paris, 328: 847-852.

JANIS, C. M. (1986): An estimation of tooth volume and hypsodonty indices in ungulate mammals, and the correlation of these factors with dietary preferences. Mémoires du Museum National d'Histoire Naturelle, Paris (série C), 53: 367-387.
JANIS, C. M. (1993): Tertiary mammal evolution in the context of changing climates, vegetation, and tectonic events. Annual Review of Ecology and Systematics, 24: 467-500.

Janis, C. M., Damuth, J. \& Theodor, J. M. (2004): The species richness of Miocene browsers, and implications for habitat type and primary productivity in the North American grassland biome. - Palaeogeography, Palaeoclimatology, Palaeoecology, 207: 371-398.

JerNVAll, J. \& ForTelius, M. (2002): Common mammals drive the evolutionary increase of hypsodonty in the Neogene. - Nature, 417: 538-540.

KäLIN, D. (1997): The mammal zonation of the Upper Marine Molasse of Switzerland reconsidered. A local biozonation of MN2-MN5. - In: AGUILAR, J.-P., Legendre, S. \& Michaux, J. (Eds.): Actes du Congrès BiochroM'97. - Mémoires et Travaux de l'Ecole Pratique des Hautes Etudes, Institut de Montpellier, 21: 515-535.

KaUfMANN, F. J. (1860): Untersuchung über die mittel- und ostschweizerische subalpine Molasse. - Neue Denkschriften der Schweizerischen Naturforschenden Gesellschaft, 77.

Kempf, O., Bolliger, T., Kälin, D., Engesser, B. \& MAtTer, A. (1997): New magnetostratigraphic calibration of Early to Middle Miocene Mammal biozones of the North Alpine foreland basin. - In: AgUILAR, J.-P., Legendre, S. \& Michaux, J. (Eds.): Actes du Congrès BiochroM'97. - Mémoires et Travaux de l'Ecole Pratique des Hautes Etudes, Institut de Montpellier, 21: 547-561.

Koenigswald von, W., Martin, T., Mörs, T. \& PfretzSCHNER, H. U. (1992): Die oberoligozäne Wirbeltierfauna von Rott bei Hennef am Siebengebirge Synonymien und Literatur 1828-1991. - Bonn (Decheniana), 145: 312-340.

KÖNIGSWALD vON, R. (1930): Die Tapirreste aus dem Aquitan von Ulm und Mainz. - Palaeontographica, 73: $1-30$.

KordikovA, E. G. (2001): Remarks on the Oligocene-Miocene mammal paleontology and sequence stratigraphy of South-Western Betpakdala Steppe, South Kazakhstan. Neues Jahrbuch für Geologie und Paläontologie Abhandlungen, 221: 35-79.

LAVOCAT, R. (1951): Révision de la faune des mammifères oligocènes d'Auvergne et du Velay. - 153 pp., Paris (Sciences et Avenir).

LEGENDRE, S. (1989): Les communautés de mammifères du Paléogène (Eocène supérieur et Oligocène) d'Europe occidentale: structures, milieux et évolution. - Münchner Geowissenschaftliche Abhandlungen, 16: 110 pp.

Lihoreau, F. \& DucrocQ, S. (2007): Family Anthracotheriidae. - In: Prothero, D. R. \& Foss, S. E (Eds.): The Evolution of Artiodactyls, 89-105; Baltimore (The John Hopkins University Press).

MADE VAN DER, J. (1999): Superfamily Hippopotamoidea. In: Rössner, G. E. \& Heissig, K. (Eds.): The Miocene Land Mammals of Europe, 203-208; München (Verlag Dr. Friedrich Pfeil). 
Marivaux, L., Chaimanee, Y., Yamee, C., Srisuk, P. \& JAEGER, J.-J. (2004): Discovery of Fallomus ladakhensis NANDA \& SAHNI, 1998 (Mammalia, Rodentia, Diatomyidae) in the lignites of Nong Ya Plong (Phetchaburi Province, Thailand): systematic, biochronological and paleoenvironmental implications. - Geodiversitas, 26: 493-507.

Mayet, L. (1908): Etude des mammifères miocènes des sables de l'Orléanais et des Faluns de la Touraine. Annales de l'Université de Lyon, 1: 1-321.

MeIn, P. (1989): Updating of MN zones. - In: LindsAY, E. H., Fahlbusch, V. \& Mein, P. (Eds.): European Neogene Mammal Chronology. - NATO Advanced Science Institutes Series, Life Scences, New York, London (Plenum Press), 180: 73-80.

MeIN, P. (1999): European Miocene mammal biochronology. - In: Rössner, G. E. \& Heissig, K. (Eds.): The Miocene Land Mammals of Europe. 25-38, München (Verlag Dr. Friedrich Pfeil).

MeulenKamp, J. E. \& Sissingh, W. (2003): Tertiary palaeogeography and tectonostratigraphic evolution of the Nothern and Southern Peri-Tethys platforms and the intermediate domains of the Africa-Eurasian boundary zone. - Palaeogeography, Palaeoclimatology, Palaeoecology, 196: 209-228.

MicHEL, P. (1983): Contribution à l'étude des Rhinocérotidés oligocènes : (La Milloque; Thézels; Puy de Vaurs). - Thèse 3ème cycle, University of Poitiers, 926: 209 pp.

MinlbaChler, M. C. (2005): Linking sexual dimorphism and sociality in rhinoceroses: insights from Teleoceras proterum and Aphelops malacorhinus from the Late Miocene of Florida. - Bulletin of the Florida Museum of Natural History, 45: 495-520.

Mödden, C. (1994): Systematik und Nomenklatur der Issiodoromyinae TullBERG, 1899 (1884) (Rodentia, Theridomyidae) des europäischen Paläogen. - Eclogae geologicae Helvetiae, 87: 1037-1066.

Montoya, P., Peñalver, E., Ruis-Sanchez, F., SantiSteban, C. D., Alcazlá, L., Belinchón, M. \& LACOMBA, J. L. (1996): Los yacimientos paleontologicos de la cuenca terciaria continental de Rubielos de Mora (Aragón). - Revista Español de Paleontologia, Junio 1996, 215-224.

Morales, J. \& SoriA, D. (1984): Los Artiodáctilos del Mioceno inferior de las cuencas centrales de España. Publicaciones de Departamento de Paleontología, 39: 51-60

Mörs, T. (2002): Biostratigraphy and paleoecology of continental Tertiary vertebrate faunas in the Lower Rhine Embayment (NW-Germany). - Netherland Journal / Geologie en Mijnbouw, 81: 177-183.

Mosbrugger, V., Utescher, T. \& Dilcher, D. L. (2005): Cenozoic continental climatic evolution of Central Europe. - Proceedings of the National Academy of Sciences of the United States of America, 102/42: 14964-14969.

Murelaga, X., Astibia, H., Sesé, C., Soria, D. \& PeredaSuberbiolA, X. (2004): Mamíferos del Mioceno inferior de las Bardenas Reales de Navarra (Cuenca del Ebro, Península Ibérica). Lower Miocene Mammals from Bardenas Reales of Navarre (Ebro Basin, Iberian
Peninsula). - Munibe (Ciencias Naturales-Natur Zientziak), 55: 7-102.

Nouel, A. (1866): Mémoire sur un nouveau Rhinocéros fossile. - Mémoires de la Société Agricole et Scientifique, Orléans, 7: 13 pp.

NowAK, R. M. (1999): Walker's Mammals of the World. 2015 pp.; 6 ${ }^{\text {th }}$ Edition, 2 volumes, Baltimore, Maryland (The Johns Hopkins University Press).

Ooster, W.-A. \& Fischer-Ooster von, C. (1871): Merkwürdige Thier- und Pflanzenreste der schweizerischen Vorwelt. - Protozoe Helveticae, Mittheilungen aus dem Berner Museum der Naturgeschichte, 2: 1-8.

OsBorN, H. F. (1900): Phylogeny of the Rhinoceroses of Europe. - Bulletin of the American Museum of Natural History, New York, 13: 229-267.

Pomel, M. (1853): Catalogue méthodologique et descriptif des vertébrés fossiles découverts dans le bassin hydrographique supérieur de la Loire, et surtout dans la vallée de son affluent principal, l'Allier. - 76-77; Paris (Baillière Ed.)

Prothero, D. R. (1994): Mammalian evolution. - In: Prothero, D. R. \& Schoch, R. M. (Eds.): Major Features of Vertebrate Evolution. - Paleontological Society Short Courses in Paleontology, 7: 238-270.

Prothero, D. R. (1999): Does climatic change drive mammalian evolution? - GSA Today, 9: 1-7.

Prothero, D. R. (2005): The Evolution of North American Rhinoceroces. - 218 pp; Cambridge (Cambridge University Press).

Prothero, D. R. \& Schoch, R. M. (1989): Classification of the Perissodactyla. - In: Prothero, D. R. \& Schoch, R. M. (Eds.): The Evolution of Perissodactyls. - 530-537; New York (Oxford University Press).

Prothero, D. R., Manning, E. \& Hanson, C. B. (1986): The phylogeny of the Rhinocerotoidea (Mammalia, Perissodactyla). - Zoological Journal of the Linnean Society, 87: 341-366.

Prothero, D. R., GuÉrin, C. \& Manning, E. (1989): The History of the Rhinocerotoidea. - In: Prothero, D. R. \& SCHOCH, R. M. (Eds.): The Evolution of Perissodactyls. - 322-340; New York (Oxford University Press).

Quiralte, V. \& Morales, J. (2006): Los Rumiantes (Artiodactyla, Mammalia) del Mioceno inferior de La Encinilla (Colmenar Viejo, Madrid). - Estudios Geológicos, 62: 515-532.

Reichenbacher, B., Uhlig, U., Kowalke, T., Bassler, B., MatzKe-Karasz, R. \& SchenK, B. (2004): Biota, palaeoenvironments and biostratigraphy of contiental Oligocene deposits of the South German Molasse Basin (Penzberg Syncline). - Palaeontology, 47: 639-677.

RÉPELIN, J. (1917): Etudes paléontologiques dans le sudouest de la France (Mammifères). Les Rhinocérotidés de l'Aquitanien supérieur de l'Agenais (Laugnac). Annales du Muséum d'Histoire Naturelle de Marseille, 16: $1-47$.

RöGL, F. (1999): Circum-Mediterranean Miocene Paleogeography. - In: Rössner, G. E. \& Heissig, K. (Eds.): The Miocene Land Mammals of Europe, 39-48; München (Verlag Dr. Friedrich Pfeil). 
Roman, F. (1911): Les Rhinocérotidés de l'Oligocène d'Europe. - Archives du Muséum d'Histoire Naturelle de Lyon, 11: $92 \mathrm{pp}$.

- (1924): Contribution à l'étude de la faune de Mammifères des Littorinenkalk (Oligocène supérieur) du bassin de Mayence. Les Rhinocéros. - Travaux du Laboratoire de Géologie de la Faculté des Sciences de Lyon, 7: 1-54.

Sach, V. J. \& Heizmann, E. P. J. (2001): Stratigraphie und Säugetierfaunen der Brackwassermolasse in der Umgebung von Ulm (Südwestdeutschland). - Stuttgarter Beiträge zur Naturkunde, B/310; 95 pp.

Santafé Llopis, J. V. (1978): Rhinocerotidos fosiles de España. - Unpublished PhD Thesis, University of Barcelona, $488 \mathrm{pp}$.

Schaub, S. (1928): Der Tapirschädel von Haslen. Ein Beitrag zur Revision der Tapiriden Europas. - Mémoires Suisses de Paléontologie, 47: 1-28.

Schaub, S. \& Hürzeler, J. (1948): Die Säugetierfauna des Aquitanien vom Wischberg bei Langenthal. - Eclogae geologicae Helvetiae, 41: 354-366.

Schindel, R., Buob, S. \& Flisch, A. (2008): Prähistorisches Nashorn mit Termin beim Rasiologen. - Berichte der St. Gallischen Naturwissenschaftlichen Gesellschaft, 91: 135-142.

Schlanke, S. (1974): Geologie der subalpinen Molasse zwischen Biberbrugg/SZ, Hütten/ZH und Aegerisee/ZG, Schweiz. - Eclogae geologiae Helvetiae, 67: 243.

Schlunegger, F., Melzer, J. \& Tucker, G. E. (2001): Climate, exposed source-rock lithologies, crustal uplift and surface erosion: a theoretical analysis calibrated with data from the Alps/North Alpine Foreland Basin system. - International Journal of Earth Sciences, 90: 484-499.

ScHMIDT-KitTler, N. (1987): European reference levels and correlation tables. - Münchner Geowissenschaftliche Abhandlungen, 10: 13-19.

Schmidt-Kittler, N., Vianey-Liaud, M., Mödden, C. \& Comte, B. (1997): New data for the correlation of mammal localities in the European Oligocene: biochronological relevance of the Theridomyidae. - In: Aguilar, J.-P., Legendre, S. \& Michaux, J. (Eds.): Actes du Congrès BiochroM'97. - Mémoires et Travaux de l'Ecole pratique des Hautes Etudes, Institut de Montpellier, 21: 375-395.

SCHUlER, M. (1990): Environnements et paléoclimats paléogènes : palynologie et biostratigraphie de l'Eocène et de l'Oligocène inférieur dans le Fossé rhénan, rhodanien et de Hesse. - Document du Bureau de Recherches Géologiques et Minières, 190: $535 \mathrm{pp}$.

Stehlin, H. G. (1914): Übersicht über die Säugetiere der schweizerischen Molasseformation, ihre Fundorte und ihre stratigraphische Verbreitung. - Verhandlungen der Naturforschenden Gesellschaft Basel, 21: 165-185.

Steininger, F. F. (1999): Chronostratigraphy, Geochronology and Biochronology of the Miocene "European Land Mammal Mega-Zones (ELMMZ)" and the Miocene "Mammal-Zones (MN-zones)". - In: Rössner, G. E. \& Heissig, K. (Eds.): The Miocene Land Mammals of Europe, 9-24; München (Verlag Dr. Friedrich Pfeil).
StUder, B. (1853): Geologie der Schweiz. Volume 2. 497 pp., Bern (Stämpfli).

TAssy, P. (1989): The "Proboscidean Datum Event": how many proboscideans and how many events? - In: Lindsay, E. H., Fahlbusch, V. \& MeIn, P. (Eds.): European Neogene Mammal Chronology. - NATO Advanced Science Institutes Series, Life Scences, New York, London (Plenum Press), 180: 237-252.

Tobien, H. (1980): Taxonomic status of some Cenozoic mammalian local faunas from the Mainz Basin. - Mainzer Geowissenschaftliche Mitteilungen, 9: 203-235.

Uhlig, U. (1999): Die Rhinocerotidea (Mammalia) aus der unteroligozänen Spaltenfüllung Möhren 13 bei Treuchlingen in Bayern. - Abhandlungen der Bayerische Akademie der Wissenschaften, Mathematisch-Naturwissenschaftliche Klasse, Neue Folge, 170: 254 pp.

ViANEY-LiAud, M. (2003): Gliridae (Mammalia, Rodentia) de l'Oligocène européen: origine de trois genres miocènes. - Coloquios de Paleontologia, Vol. Ext., 1: 669698.

Whybrow, P. J. \& Andrews, P. (2000): Response of Old World terrestrial vertebrate biotas to Neogene climate change. The Last 145 Million Years. - In: Cluver, S. J. \& Rawson, P. F. (Eds.): Biotic Response to Global Change. - 350-398; Cambridge (Cambridge University Press).

Zachos, J., Pagani, M., Sloan, L., Thomas, E. \& Billups, K. (2001): Trends, Rhythms, and Aberrations in Global Climate 65 Ma to Present. - Science, 292: 686-693.

\section{Addresses of the authors:}

DAMIEN Becker, Section d'archéologie et paléontologie, Office de la culture, République et Canton du Jura, Hôtel des Halles, CH-2900 Porrentruy, Switzerland.

e-mail: damien.becker@palaeojura.ch

TONI BÜRgIN, Naturmuseum, Museumstrasse 32, CH-9000 St. Gallen, Switzerland.

e-mail: toni.buergin@naturmuseumsg.ch

Urs OBERLi, Waldgutstrasse 28, CH-9010 St. Gallen, Switzerland.

e-mail: oberliurs@gmx.ch

LAURELINE SCHERLER, University of Fribourg, Department of Geosciences, Chemin du Musée 6, CH-1700 Fribourg, Switzerland.

e-mail: laureline.scherler@unifr.ch 